This document is the accepted manuscript version of the following article:

Payandeh, S. H., Asakura, R., Avramidou, P., Rentsch, D., Łodziana, Z., Černý, R., ... Battaglia, C. (2020). Nido-Borate/Closo-borate mixed-anion electrolytes for a11-solid-state batteries. Chemistry of Materials.

https://doi .org/10.1021/acs. chemmater.9b03933

\title{
Nido-Borate/Closo-Borate Mixed-Anion Electrolytes for All-Solid-State Batteries
}

SeyedHosein Payandeha ${ }^{a}$, Ryo Asakura ${ }^{\mathrm{a}}$, Petroula Avramidou ${ }^{\mathrm{a}}$, Daniel Rentsch ${ }^{\mathrm{a}}$, Zbigniew Łodziana $^{\mathrm{b}}$, Radovan Černýc ${ }^{\mathrm{c}}$, Arndt Remhof ${ }^{\mathrm{a}}$, Corsin Battaglia ${ }^{\mathrm{a}}$

aEmpa, Swiss Federal Laboratories for Materials Science and Technology, 8600 Dübendorf, Switzerland.

bPolish Academy of Sciences, Institute of Nuclear Physics, ul, Radzikowskiego 152, 31-342, Kraków, Poland.

'Laboratory of Crystallography, Department of Quantum Matter Physics, University of Geneva, Quai Ernest-Ansermet 24, 1211, Geneva, Switzerland

\section{Corresponding Author}

*Email: arndt.remhof@empa.ch

\begin{abstract}
Closo-borates and carba-closo-borates recently emerged as a promising class of solid electrolytes for all-solid-state batteries, but are too expensive. Here we introduce $\mathrm{NaB}_{11} \mathrm{H}_{14}$ nido-borates as a new building block for solid electrolytes that can be synthesized via a costeffective low-temperature method using cheap $\mathrm{NaBH}_{4}$ as a chemical feedstock. We employ 2D nuclear magnetic resonance techniques to analyze the structure of this new building block. High ionic conductivity of up to $4 \mathrm{mS} / \mathrm{cm}$ at $20{ }^{\circ} \mathrm{C}$ is achieved by combining nido- $\mathrm{NaB}_{11} \mathrm{H}_{14}$ with closo- $\mathrm{Na}_{2} \mathrm{~B}_{12} \mathrm{H}_{12}$ into cubic unit cells. Importantly, $\mathrm{Na}_{2} \mathrm{~B}_{12} \mathrm{H}_{12}$ can also be synthesized costeffectively from $\mathrm{NaBH}_{4}$. Crystal structures are solved and refined by synchrotron X-ray diffraction and density functional theory. Cyclic voltammetry reveals electrochemical stability from 0.15 to $2.6 \mathrm{~V}$ vs Na/ $\mathrm{Na}^{+}$. Galvanostatic cycling in symmetrical cells with sodium metal electrodes shows only a small overpotential increase from $2 \mathrm{mV}$ to $2.5 \mathrm{mV}$ after 400 cycles at $50 \mu \mathrm{A} / \mathrm{cm}^{2}$. We also discuss how our results can be translated to render lithium solid electrolytes economically viable.
\end{abstract}




\section{Introduction}

All-solid-state batteries (ASSBs) are considered as next-generation battery technology promising improved safety and higher energy and power density than today's lithium-ion batteries, employing flammable liquid electrolytes. The key component of an all-solid-state battery is the solid electrolyte, which is required to exhibit high ionic conductivity of $\sim 1 \mathrm{mS} / \mathrm{cm}$ at room temperature, a low activation energy to enable battery operation over a large temperature range, chemical and electrochemical compatibility with anode and cathode, high thermal stability, and appropriate mechanical properties. ${ }^{1,2}$

Prominent candidate solid electrolytes include oxides, sulfides, and polymers. ${ }^{3-6}$ Oxide electrolytes are brittle ceramics and therefore it is challenging to compensate volume variations of anode and/or cathode during cycling without crack formation. Sulfides are softer, but suffer from a narrow electrochemical stability window and tend to release toxic hydrogen sulfide gas when exposed to humidity. ${ }^{7,8}$ Polymer electrolytes have already been commercialized in all-solid-state batteries but are not yet compatible with $4 \mathrm{~V}$ class cathode materials resulting in an energy density inferior to today's liquid-electrolyte lithium-ion batteries. ${ }^{4}$ Recently, hydroborate electrolytes have emerged as a promising yet underexplored class of solid electrolytes exhibiting high ionic conductivity $>1$ $\mathrm{mS} / \mathrm{cm}$, compatibility with lithium and sodium metal anodes, and ductile mechanical properties that enabled integration into an all-solid-state battery demonstrating excellent capacity retention of $85 \%$ after 250 cycles at $\mathrm{C} / 5 .{ }^{9-18}$

Currently, one of the major challenges towards an economically viable hydroborate all-solid-state battery technology is the cost of the building blocks for hydroborate electrolytes. High-ionic conductivity is achieved by integrating different closed-cage closo-borate or carba-closo-borate building blocks (see Fig. 1a-c) into the electrolyte's crystal lattice. ${ }^{9,12-14}$ With 120 '000 $€ / \mathrm{kg}$ for the closo- $\mathrm{Na}_{2} \mathrm{~B}_{10} \mathrm{H}_{10}$ and $254^{\prime} 000 € / \mathrm{kg}$ for the carba-closo- $\mathrm{NaCB}_{11} \mathrm{H}_{12}$ and similar prices for their 
lithium analogues, ${ }^{19}$ these salts are too expensive for battery applications. Even though prices may drop with new synthesis routes, ${ }^{20}$ alternatives are sought.

Recently $\mathrm{NaB}_{11} \mathrm{H}_{14}$ was investigated as a solid electrolyte. ${ }^{21}$ Here, we explore the synthesis, structure and electrochemical properties of this material in more detail, moreover, we introduce open-cage nido-borates (see Fig. 1d) as a building block for solid electrolytes. Nido- $\mathrm{NaB}_{11} \mathrm{H}_{14}$ is synthesized from $\mathrm{NaBH}_{4}\left(\sim 20 \$ / \mathrm{kg}^{22}\right)$ using a cost-effective low-temperature method. In particular, the synthesis avoids the use of expensive, toxic, and explosive decaborane $\left(\mathrm{B}_{10} \mathrm{H}_{14}\right)$ typically employed in the synthesis of closo- $\mathrm{Na}_{2} \mathrm{~B}_{10} \mathrm{H}_{10}$ and carba-closo-borates. ${ }^{19,23,24}$ Combining monovalent nido- $\mathrm{B}_{11} \mathrm{H}_{14}{ }^{-}$anions and divalent closo- $\mathrm{B}_{12} \mathrm{H}_{12}{ }^{2-}$ building blocks into a cubic lattice, we show that a high sodium ion conductivity of up to $4 \mathrm{mS} / \mathrm{cm}^{2}$ can be achieved at room temperature. As closo- $\mathrm{Na}_{2} \mathrm{~B}_{12} \mathrm{H}_{12}$ can also be synthesized cost-effectively from $\mathrm{NaBH}_{4},{ }^{25,26}$ our results show that hydroborate electrolytes can be made economically viable for all-solid-state batteries.

\section{Experimental}

$\mathrm{NaB}_{11} \mathrm{H}_{14}$ can be synthesized by reacting $\mathrm{NaBH}_{4}$ and $\mathrm{B}_{10} \mathrm{H}_{14}$ in dioxane $\left(\mathrm{C}_{4} \mathrm{H}_{8} \mathrm{O}_{2}\right)$ resulting in the formation of $\mathrm{NaB}_{11} \mathrm{H}_{14}\left(\mathrm{C}_{4} \mathrm{H}_{8} \mathrm{O}_{2}\right)_{\mathrm{n}}$ as solid product (method 1, ${ }^{27}$ eq. 1, see SI for details).

$\mathrm{NaBH}_{4}(\mathrm{~s})+\mathrm{B}_{10} \mathrm{H}_{14}(\mathrm{sol}) \stackrel{\text { Dioxane, } 90^{\circ} \mathrm{C}}{\rightleftharpoons} \mathrm{NaB}_{11} \mathrm{H}_{14}\left(\mathrm{C}_{4} \mathrm{H}_{8} \mathrm{O}_{2}\right)_{\mathrm{n}}(\mathrm{s})+2 \mathrm{H}_{2}(\mathrm{~g})$

$\mathrm{NaB}_{11} \mathrm{H}_{14}$ can be extracted by dissolving the product in water and removing the coordinated solvents by heat treatment. ${ }^{27}$ In order to avoid the use of $\mathrm{B}_{10} \mathrm{H}_{14}$, an alternative synthetic approach was employed reacting $\mathrm{NaBH}_{4}$ and 1-promopentane $\left(\mathrm{C}_{5} \mathrm{H}_{11} \mathrm{Br}\right)$ in digylme (method 2, eq. 2, Tab. 1, see SI for details). ${ }^{28}$

$11 \mathrm{NaBH}_{4}(\mathrm{sol})+10 \mathrm{C}_{5} \mathrm{H}_{11} \mathrm{Br}(\mathrm{l}) \stackrel{\text { Diglyme, }{ }^{110^{\circ} \mathrm{C}}}{\longrightarrow} \mathrm{NaB}_{11} \mathrm{H}_{14} \cdot(\text { diglyme })_{\mathrm{n}}(\mathrm{sol})+10 \mathrm{C}_{5} \mathrm{H}_{12}(\mathrm{l})+10$ $\mathrm{NaBr}(\mathrm{s})+10 \mathrm{H}_{2}(\mathrm{~g})$ 
Both reactants and the solvent are cheap and readily available allowing cost-effective upscaling of the synthesis. Digylme strongly coordinates with the $\mathrm{Na}$ ion and makes the precipitation of the $\mathrm{NaB}_{11} \mathrm{H}_{14}$.(diglyme) $)_{n}$ complex impossible without decomposition. In order to overcome this challenge, sodium ions are substituted with $\mathrm{Me}_{3} \mathrm{NH}^{+}$allowing the precipitation of $\mathrm{Me}_{3} \mathrm{NHB}_{11} \mathrm{H}_{14}$ and removing the coordinating diglyme (Fig. S1, eq. 3).

$$
\begin{aligned}
& \left.\mathrm{NaB}_{11} \mathrm{H}_{14} \text {. (diglyme }\right)_{\mathrm{n}}(\mathrm{sol})+\mathrm{Me}_{3} \mathrm{NHCl}(\mathrm{sol}) \stackrel{\text { Water }}{\longrightarrow} \mathrm{Me}_{3} \mathrm{NHB}_{11} \mathrm{H}_{14}(\mathrm{~s})+\mathrm{NaCl}(\text { sol })+\operatorname{diglyme} \\
& \quad(\text { sol })
\end{aligned}
$$

Finally, the reaction of $\mathrm{Me}_{3} \mathrm{NHB}_{11} \mathrm{H}_{14}$ with $\mathrm{NaOH}$ or $\mathrm{NaHCO}_{3}$ in water or $\mathrm{NaH}$ in THF leads to the isolation of $\mathrm{NaB}_{11} \mathrm{H}_{14}$ (Fig.S2, eq. 4).

$\mathrm{Me}_{3} \mathrm{NHB}_{11} \mathrm{H}_{14}(\mathrm{sol})+\mathrm{NaH}(\mathrm{s}) \stackrel{\mathrm{THF}}{\longrightarrow} \mathrm{NaB}_{11} \mathrm{H}_{14}$ (sol) $+\mathrm{Me}_{3} \mathrm{~N}(\mathrm{~g})+\mathrm{H}_{2}$ (g)

The purity of $\mathrm{NaB}_{11} \mathrm{H}_{14}$ and the molecular structure of the $\mathrm{B}_{11} \mathrm{H}_{14}{ }^{-}$anion was analyzed by nuclear magnetic resonance (NMR). To reach an ionic conductivity $>1 \mathrm{mS} / \mathrm{cm}$, nido- $\mathrm{NaB}_{11} \mathrm{H}_{14}$ was mixed with closo- $\mathrm{Na}_{2} \mathrm{~B}_{12} \mathrm{H}_{12}$ in a ball mill at molar ratios of $2: 1,1: 1$, and 1:2 (Tab. 1). The crystal structures of the resulting materials were analyzed by synchrotron powder X-ray diffraction $(\mathrm{PXRD})^{29,30}$ and solved ab initio with direct space modeling using global optimization methods implemented into Fox. ${ }^{30}$ Crystal structures were further optimized by density functional theory as implemented in the Vienna ab initio simulation package (VASP). Phase transitions and decomposition reactions were studied by combined thermogravimetric analysis (TGA) and differential scanning calorimetry (DSC). Ionic conductivity and electrochemical stability window were measured by electrochemical impedance spectroscopy and linear sweep voltammetry (LSV), respectively. For details see Supporting Information. 
Table 1 Overview of the investigated compounds, synthesis procedures, and compositions determined by PXRD and ${ }^{11} \mathrm{~B}\left\{{ }^{1} \mathrm{H}\right\}$ NMR.

Figure 1 Atomic structure of the a) $\mathrm{B}_{12} \mathrm{H}_{12}{ }^{2-}$, b) $\mathrm{CB}_{11} \mathrm{H}_{12}{ }^{-}$, c) $\mathrm{B}_{10} \mathrm{H}_{10}{ }^{2-}$ and d) $\mathrm{B}_{11} \mathrm{H}_{14}$ - polyanions. Boron is denoted by green and blue, carbon by brown and hydrogen by white balls. e) ${ }^{11} \mathrm{~B}\left\{{ }^{1} \mathrm{H}\right\}$ NMR spectra of the synthesized samples in DMSO- $\mathrm{d}_{6}$ solutions.

\section{Results and Discussion}

The purity of $\mathrm{NaB}_{11} \mathrm{H}_{14}$ was verified by ${ }^{11} \mathrm{~B}$ solution-state NMR in DMSO-d $\mathrm{d}_{6}$ shown in Fig. 1e. The reaction of $\mathrm{NaBH}_{4}$ with $\mathrm{B}_{10} \mathrm{H}_{14}$ (method 1) often results in $\mathrm{Na}_{2} \mathrm{~B}_{12} \mathrm{H}_{12}$ impurities being present in the reaction products, while the reaction scheme with $\mathrm{C}_{5} \mathrm{H}_{11} \mathrm{Br}$ (method 2) results in $\mathrm{NaB}_{11} \mathrm{H}_{14}$ with high purity with no indication of $\mathrm{Na}_{2} \mathrm{~B}_{12} \mathrm{H}_{12}$ impurity. In this method, excess use of $\mathrm{Me}_{3} \mathrm{NHB}_{11} \mathrm{H}_{14}$ 
is crucial for cation exchange to avoid oxidation of the $\mathrm{B}_{11} \mathrm{H}_{14^{-}}$cage in eq. 4 . For this purpose, using $\mathrm{NaH}$ in THF is more promising than aqueous solution, since $\mathrm{NaH}$ is not soluble and cannot oxidize the cage in the presence of excess $\mathrm{Me}_{3} \mathrm{NHB}_{11} \mathrm{H}_{14}$ (Fig. S2).

To confirm the atomic arrangement of the $\mathrm{B}_{11} \mathrm{H}_{14}$ - anion building block, we performed ${ }^{1} \mathrm{H}-{ }^{1} \mathrm{H},{ }^{1} \mathrm{H}-$ ${ }^{11} \mathrm{~B}$ and ${ }^{11} \mathrm{~B}-{ }^{11} \mathrm{~B}$ correlated 2D NMR of $\mathrm{NaB}_{11} \mathrm{H}_{14}$ in DMSO- $\mathrm{d}_{6}$ solution (Fig. 2a-c). The data allows assigning chemical shifts to the individual boron and hydrogen atoms in the cage by spin-spin couplings between adjacent nuclei and discloses atomic connectivity in the polyhedral framework. The resonance at $\delta^{11} \mathrm{~B}$ of $-14.2 \mathrm{ppm}$ with the lowest relative signal intensity is assigned to boron 1 at the bottom of the cage and in the ${ }^{11} \mathrm{~B}-{ }^{11} \mathrm{~B}$ correlated NMR spectrum (Fig. 2a) the cross signal at $-14.2 /-16.8 \mathrm{ppm}$ leads to the assignment of the boron 2 sites in the middle of the $\mathrm{B}_{11} \mathrm{H}_{14^{-}}$cage and subsequently, site 3 is assigned via the cross signal at $\delta^{11} \mathrm{~B}-16.0 /-16.8 \mathrm{ppm}$. From the correlations observed in the ${ }^{1} \mathrm{H}-{ }^{11} \mathrm{~B}$ HSQC spectrum (Fig. 2b), the four types of hydrogens in $\mathrm{NaB}_{11} \mathrm{H}_{14}$ can be assigned as follows: The single boron at site $1\left(\delta^{11} \mathrm{~B}=-14.2 \mathrm{ppm}\right)$ shows a correlation to a proton at site $\mathrm{A}$ at $1.8 \mathrm{ppm}$, the five protons (B) at $1.2 \mathrm{ppm}$ correlate to the boron atoms at site 2 in the middle of the cage and finally, two different hydrogen species with $\delta^{1} \mathrm{H}$ at 1.6 and $-3.6 \mathrm{ppm}$ are assigned to sites $\mathrm{C}$ (5 protons) and $\mathrm{D}$ (3 protons) at the top of the cage, respectively. All hydrogens show ${ }^{3} \mathrm{~J}$ coupling with their adjacent neighbors such as $(\mathrm{A} \leftrightarrow \mathrm{B}, \mathrm{B} \leftrightarrow \mathrm{C}, \mathrm{B} \leftrightarrow \mathrm{D}, \mathrm{C} \leftrightarrow \mathrm{D}$ black arrows, although the $\mathrm{B} \leftrightarrow \mathrm{D}$ cross-peaks might also originate from $\mathrm{a}^{2} \mathrm{~J}$ coupling). Note that the homonuclear correlations (Fig. 2a and 2c) were both recorded with simultaneous decoupling of ${ }^{1} \mathrm{H}$ or ${ }^{11} \mathrm{~B}$ during the whole pulse sequences, respectively, since due to the relatively large ${ }^{1} \mathrm{~J}\left({ }^{1} \mathrm{H},{ }^{11} \mathrm{~B}\right)$ coupling in the order of $130 \mathrm{~Hz}$ the polarizations were not properly transferred without decoupling.

The three hydrogen atoms at site D appear at very low frequency and the observation of only one resonance suggests only one type of hydrogen for this position. However, two different bonding 
configurations are described in the literature for hydrogen atoms on the open side of the cage such as three bridging hydrogen atoms (B-H-B) or two bridging (B-H-B) and one endo-hydrogen (B-H) atoms. ${ }^{31}$ Analysis of the structure and the charge density distribution on the $\mathrm{B}_{11} \mathrm{H}_{14}{ }^{-}$anion by density functional theory in vacuum confirms that the configuration with two bridging $\mathrm{H}$ atoms and one endo- $\mathrm{H}$ atom is by $30 \mathrm{meV}$ more stable than the configuration with three bridging $\mathrm{H}$ atoms. Moreover, calculations of the crystalline state stability did not yield a structure with three bridging $\mathrm{H}$. Therefore, we applied the configuration with two bridging $\mathrm{H}$ atoms and one endo- $\mathrm{H}$ for solving the crystal structures. This configuration was also employed previously for the determination of the crystal structure of $\left[\mathrm{Ph}_{3} \mathrm{PH}\right]\left[\mathrm{B}_{11} \mathrm{H}_{14}\right] .{ }^{32}$

Figure 2 a) ${ }^{11} \mathrm{~B}-{ }^{11} \mathrm{~B}\left\{{ }^{1} \mathrm{H}\right\}$ DQF-COSY, b) ${ }^{1} \mathrm{H}-{ }^{11} \mathrm{~B}$ HSQC c) ${ }^{1} \mathrm{H}-{ }^{1} \mathrm{H}\left\{{ }^{11} \mathrm{~B}\right\}$ DQF-COSY solution-state 2D NMR spectra of $\mathrm{NaB}_{11} \mathrm{H}_{14}$ with assignments of resonances and d-f) solid-state ${ }^{1} \mathrm{H},{ }^{11} \mathrm{~B}$ and ${ }^{23} \mathrm{Na}$ MAS NMR spectra of $\mathrm{Na}_{2} \mathrm{~B}_{12} \mathrm{H}_{12}, \quad \mathrm{NaB}_{11} \mathrm{H}_{14}$ and $\mathrm{Na}_{\mathrm{x}+2 \mathrm{y}}\left(\mathrm{B}_{11} \mathrm{H}_{14}\right)_{\mathrm{x}}\left(\mathrm{B}_{12} \mathrm{H}_{12}\right)_{\mathrm{y}}$ compounds with $\mathrm{x}: \mathrm{y}$ ratios of $2: 1,1: 1,1: 2$.

To verify that $\mathrm{B}_{11} \mathrm{H}_{14}{ }^{-}$and $\mathrm{B}_{12} \mathrm{H}_{12}{ }^{2-}$ remain intact during ball milling, we employed solid-state ${ }^{1} \mathrm{H}$, ${ }^{11} \mathrm{~B}$, and ${ }^{23} \mathrm{Na}$ MAS NMR shown in Fig 2d-f and solution-state ${ }^{11} \mathrm{~B}\left\{{ }^{1} \mathrm{H}\right\}$ NMR (Fig. S3, DMSO solutions). The spectra from mixed-anion compounds $\mathrm{Na}_{\mathrm{x}+2 \mathrm{y}}\left(\mathrm{B}_{11} \mathrm{H}_{14}\right)_{\mathrm{x}}\left(\mathrm{B}_{12} \mathrm{H}_{12}\right)_{\mathrm{y}}$ with $\mathrm{x}$ :y anion ratios of $2: 1,1: 1,1: 2$ are shown along with the spectra from the $\mathrm{NaB}_{11} \mathrm{H}_{14}$ and $\mathrm{Na}_{2} \mathrm{~B}_{12} \mathrm{H}_{12}$ precursors. The resonances of the parent compounds can be observed in the ${ }^{1} \mathrm{H}$ and ${ }^{11} \mathrm{~B}$ NMR spectra of the mixtures at the same chemical shifts confirming that both $\mathrm{B}_{11} \mathrm{H}_{14}{ }^{-}$and $\mathrm{B}_{12} \mathrm{H}_{12}{ }^{2-}$ anions still are intact in the mixtures (Fig. 2d, e, and Fig. S3). In comparison to the spectrum of the $\mathrm{Na}_{2} \mathrm{~B}_{12} \mathrm{H}_{12}$ precursor, the corresponding MAS NMR resonances in samples containing $\mathrm{NaB}_{11} \mathrm{H}_{14}$ are much narrower indicative of fast anion dynamics (Fig. 2d, e). The ${ }^{23} \mathrm{Na}$ NMR spectrum of 
$\mathrm{Na}_{2} \mathrm{~B}_{12} \mathrm{H}_{12}$ (Fig. S4a) shows a manifold of spinning side bands typical for solids where as for the mixed samples only the central transitions are observed. The central transition of $\mathrm{Na}_{2} \mathrm{~B}_{12} \mathrm{H}_{12}$ shows a line shape typical for quadrupolar interactions (experimental and simulated shapes shown in Fig. S4b). Two signals are observed for the ${ }^{23} \mathrm{Na}$ MAS NMR spectrum of $\mathrm{NaB}_{11} \mathrm{H}_{14}$ and since no sidebands are observed for this spectrum, the two resonances are assigned to different phases of $\mathrm{NaB}_{11} \mathrm{H}_{14}$ present in this sample (Fig. $2 \mathrm{f}$ ). The ${ }^{23} \mathrm{Na}$ NMR spectra of all mixed compounds show almost identical chemical shifts and line width suggests that the sodium environment in the mixtures is averaged between $\mathrm{Na}_{2} \mathrm{~B}_{12} \mathrm{H}_{12}$ and $\mathrm{NaB}_{11} \mathrm{H}_{14}$. This averaging has already been observed in the previous work. ${ }^{13}$

We now analyze the crystal structures of $\mathrm{NaB}_{11} \mathrm{H}_{14}$ and the mixed-anion compounds $\mathrm{Na}_{\mathrm{x}+2 \mathrm{y}}\left(\mathrm{B}_{11} \mathrm{H}_{14}\right)_{\mathrm{x}}\left(\mathrm{B}_{12} \mathrm{H}_{12}\right)_{\mathrm{y}}$ with $\mathrm{x}$ :y ratios of $2: 1,1: 1,1: 2$. PXRD data is shown for all four compounds in Fig. 3a. Analysis of the PXRD data of $\mathrm{NaB}_{11} \mathrm{H}_{14}$ as a function of temperature (shown in Fig. 4b) reveals the presence of two polymorphs, tentatively labeled $\alpha$ and $\beta$, which undergo a phase transition to a common high-temperature $\gamma$ phase. The $\alpha$ phase is the dominant phase at room temperature and its structure was solved in an orthorhombic unit cell with space group Pna2 $2_{1}$ (no. 33) with hexagonal closed packing ( $h c p)$ of $\mathrm{B}_{11} \mathrm{H}_{14}{ }^{-}$anions (Fig. 3b). Interestingly, a satisfactory fit of the powder reflections was obtained only after taking into account dynamic sodium disorder by introducing three types of $\mathrm{Na}$ atoms in the structure and setting their partial occupancy both in octahedral and tetrahedral sites (Fig. 3b, Fig. S5, S6). Two of the three Na atoms are located in tetrahedral sites (T), one closer to the center and another one close to the triangular face, and comprise $\sim 90 \%$ of the $\mathrm{Na}$ atoms in the structure (yellow Na atoms, Fig $3 \mathrm{~b}$ ). However, the structural model requires a small occupancy of sodium atoms in octahedral sites $(\mathrm{O}, \sim 10 \%$, red $\mathrm{Na}$ atoms, Fig. 3b). These sites are both face and edge shared with $\mathrm{T}$ sites, suggesting the $\mathrm{T} \rightarrow \mathrm{O} \rightarrow \mathrm{T}$ diffusion path for $\mathrm{Na}$ atoms (Fig. 3b). 
Density functional theory optimization of the structure indicates that Na cations are located in very shallow energy wells, and displacements of $0.3 \AA$ in each crystallographic direction are related with an energy increase of less than $5 \mathrm{meV} /$ formula unit and explains the somewhat larger vibrational ellipsoids for sodium. In all calculated structures the shortest $\mathrm{Na}-\mathrm{H}$ distance is Orthorhombic than $2.25 \AA$.

In the optimized structure, the $\mathrm{B}_{11} \mathrm{H}_{14}{ }^{-}$anion is oriented with the open side of the $\mathrm{B}_{11}$-cage away from the $\mathrm{Na}$ atoms. Analysis of the charge density of the anion by electron localization functions shows that the charge distribution at the open apex is flatter and larger charge gradients are present on the opposite or side vertexes. This results in a strong preference for Na to be located outside of the open vertex (Fig. S7). The energy difference is as large as $145 \mathrm{meV}$ in favor of $\mathrm{Na}^{+}$located at the vertex opposite to the open side, while $\mathrm{Na}^{+}$directly at the open side vertex is highly unstable ( $>800 \mathrm{meV})$. The charge density distribution was further analyzed via the Bader method, see Fig S8. In fact, this distribution strongly depends on the mutual cation anion position, with a large split of the charge for Na near the apex opposite to the open side of $\mathrm{B}_{11}$-cage.

In order to decrease the dynamic sodium disorder in the structure, additional data was recorded at $-110^{\circ} \mathrm{C}$. Changes in the relative intensity of the (011), (020), (111), and (200) Bragg reflections (Fig. S9a) suggest the ordering of the $\mathrm{Na}$ cations at this temperature. Similar behavior was previously observed for $\mathrm{Na}_{4}\left(\mathrm{~B}_{10} \mathrm{H}_{10}\right)\left(\mathrm{B}_{12} \mathrm{H}_{12}\right) \cdot{ }^{33}$ Refining the diffraction pattern at $-110{ }^{\circ} \mathrm{C}$ shows that $\mathrm{Na}$ atoms are ordered and only occupy the tetrahedral site (purple $\mathrm{Na}$ atoms in Fig. 3b, Fig. S10). This allows defining the structure based on one type of $\mathrm{Na}$ (purple atoms in the tetrahedral site) with wurtzite as aristotype. Unit cell parameters and atomic positions are summarized in Tab. 2. 
Indexing of the $\beta$ phase was hampered by the low intensity of Bragg reflections and peak overlapping with other phases. Based on combined PXRD, NMR and IR measurements we conclude that this polymorph is metastable and observed when $\mathrm{NaB}_{11} \mathrm{H}_{14}$ is heat-treated at $100{ }^{\circ} \mathrm{C}$ for $2 \mathrm{~h}$. $\beta-\mathrm{NaB}_{11} \mathrm{H}_{14}$ disappears after longer heat treatment and only $\alpha$ and $\gamma$ phases are observed in the PXRD pattern of the sample annealed for $16 \mathrm{~h}$ at $100^{\circ} \mathrm{C}$ (Fig. S14.a). $\beta-\mathrm{NaB}_{11} \mathrm{H}_{14}$ was also not observed in the previous work where samples were annealed for $16 \mathrm{~h}$ at $100{ }^{\circ} \mathrm{C} .{ }^{21}$ For the hightemperature $\gamma$ phase a cubic unit cell with space group $I-43 d$ was suggested in previous studies. ${ }^{21}$ However, this space group and unit cell did not fit our data and further attempts to find a unit cell failed.

Figure 3 a) PXRD of $\mathrm{NaB}_{11} \mathrm{H}_{14}$ and $\mathrm{Na}_{\mathrm{x}+2 \mathrm{y}}\left(\mathrm{B}_{11} \mathrm{H}_{14}\right)_{\mathrm{x}}\left(\mathrm{B}_{12} \mathrm{H}_{12}\right)_{\mathrm{y}} \cdot \bullet, \bullet, \Delta$ symbols mark the Bragg reflections of the room-temperature $\alpha$ and $\beta$ phase and the high-temperature $\gamma$ phase of $\mathrm{NaB}_{11} \mathrm{H}_{14}$, respectively $\left(\lambda_{\mathrm{Cu}}=1.5406 \AA\right)$. b-d) Crystal structures of $\mathrm{NaB}_{11} \mathrm{H}_{14}$ and $\mathrm{Na}_{\mathrm{x}+2 \mathrm{y}}\left(\mathrm{B}_{11} \mathrm{H}_{14}\right)_{\mathrm{x}}\left(\mathrm{B}_{12} \mathrm{H}_{12}\right)_{\mathrm{y}}$ compounds. In $\mathrm{NaB}_{11} \mathrm{H}_{14}$ at room temperature, sodium atoms are located in octahedral and tetrahedral positions represented by red and yellow balls. The location of sodium atoms in the ordered phase at $-110^{\circ} \mathrm{C}$ is represented by purple balls.

PXRD data of the mixed-anion $\mathrm{Na}_{\mathrm{x}+2 \mathrm{y}}\left(\mathrm{B}_{11} \mathrm{H}_{14}\right)_{\mathrm{x}}\left(\mathrm{B}_{12} \mathrm{H}_{12}\right)_{\mathrm{y}}$ compounds with $\mathrm{x}$ :y ratios of $2: 1,1: 1$, 1:2 are shown in Fig. 3a. For $\mathrm{Na}_{4}\left(\mathrm{~B}_{11} \mathrm{H}_{14}\right)_{2}\left(\mathrm{~B}_{12} \mathrm{H}_{12}\right)$ and $\mathrm{Na}_{3}\left(\mathrm{~B}_{11} \mathrm{H}_{14}\right)\left(\mathrm{B}_{12} \mathrm{H}_{12}\right)$, a phase with $I$ centered cubic cell forms (Fig. 3c). For $\mathrm{Na}_{5}\left(\mathrm{~B}_{11} \mathrm{H}_{14}\right)\left(\mathrm{B}_{12} \mathrm{H}_{12}\right)_{2}$, a primitive cubic cell (Fig. 3d) is identified due to the extra Bragg reflection at $2 \theta=25^{\circ}$ (indicated by the arrow in Fig. 3a), which is systematically extinct in the $I$-cell.

Because $\mathrm{B}_{11} \mathrm{H}_{14}{ }^{-}$is monovalent and $\mathrm{B}_{12} \mathrm{H}_{12}{ }^{2-}$ divalent, the sodium content in the structure increases with y to maintain charge balance. Taking into account that the two high-temperature phases of $\mathrm{Na}_{2} \mathrm{~B}_{12} \mathrm{H}_{12}$ consist of a $b c c$ arrangement of orientationally disordered $\mathrm{B}_{12} \mathrm{H}_{12}{ }^{2-}$ anions with primitive and $I$-centered space groups $(P m-3 n \text { and } I m-3 m)^{34}$, these structure models were used to solve the 
structures of mixed-anion $\mathrm{Na}_{\mathrm{x}+2 \mathrm{y}}\left(\mathrm{B}_{11} \mathrm{H}_{14}\right)_{\mathrm{x}}\left(\mathrm{B}_{12} \mathrm{H}_{12}\right)_{\mathrm{y}}$ compounds (Fig. S11-S13). ${ }^{34}$ The resulting Im$3 m$ structure for $\mathrm{Na}_{4}\left(\mathrm{~B}_{11} \mathrm{H}_{14}\right)_{2}\left(\mathrm{~B}_{12} \mathrm{H}_{12}\right)$ and $\mathrm{Na}_{3}\left(\mathrm{~B}_{11} \mathrm{H}_{14}\right)\left(\mathrm{B}_{12} \mathrm{H}_{12}\right)$ is fully disordered (Fig. 3c). For $\mathrm{Na}_{5}\left(\mathrm{~B}_{11} \mathrm{H}_{14}\right)\left(\mathrm{B}_{12} \mathrm{H}_{12}\right)_{2}$, the Na content in the structure increases and a $P m-3 n$ structure with partial disorder and occupancy is stabilized (Fig. 3d). The reduced disorder in this structure is expected due to the higher Na content. The $P m-3 n$ structure was already observed as an intermediate phase for $\mathrm{Na}_{2} \mathrm{~B}_{12} \mathrm{H}_{12}$, where the increase in temperature increases the disorder and $I m-3 m$ stabilizes as the final high temperature phase. ${ }^{34}$ The same behavior is observed for $\mathrm{Na}_{5}\left(\mathrm{~B}_{11} \mathrm{H}_{14}\right)\left(\mathrm{B}_{12} \mathrm{H}_{12}\right)_{2}$, which undergoes a phase transition from $P m-3 n$ to $I m-3 m$ phase at $T=254^{\circ} \mathrm{C}$ by increasing the dynamic disorder in the structure (Fig. S16a,b). Similar phases were also observed in the mixed-anion $\mathrm{Na}_{5}\left(\mathrm{CB}_{11} \mathrm{H}_{12}\right)\left(\mathrm{B}_{12} \mathrm{H}_{12}\right)_{2}$ as a function of temperature. ${ }^{14}$

In addition to the observed phases for $\mathrm{NaB}_{11} \mathrm{H}_{14}$ and mixed-anion $\mathrm{Na}_{\mathrm{x}+2 \mathrm{y}}\left(\mathrm{B}_{11} \mathrm{H}_{14}\right)_{\mathrm{x}}\left(\mathrm{B}_{12} \mathrm{H}_{12}\right)_{\mathrm{y}}$ compounds in this study, a $f c c$ phase was observed in Ref. ${ }^{21}$ for one of the commercial product batches. The formation of a cubic $f c c$ phase could be related to the presence of impurities, nevertheless, our observation of $b c c$ structures for mixed $\mathrm{Na}_{2} \mathrm{~B}_{12} \mathrm{H}_{12}: \mathrm{NaB}_{11} \mathrm{H}_{14}$ phases suggests that the $f c c$ phase reported in Ref. ${ }^{21}$ has a different origin of impurity.

Unit cell parameters determined by Rietveld refinements are summarized in Tab. 2 and the atomic positions in the new structures are presented in Tab. S1-S5.

Table 2 Structural data extracted from Rietveld refinements of the PXRD data.

\begin{tabular}{|l|l|l|l|l|}
\hline & & $\mathbf{x}: \mathbf{y}=\mathbf{2 : 1}$ & $\mathbf{x}: \mathbf{y}=\mathbf{1 : 1}$ & $\mathbf{x}: \mathbf{y}=\mathbf{1 : 2}$ \\
\hline Formula & $\mathbf{N a B}_{11} \mathbf{H}_{14}$ & $\mathbf{N a}_{\mathbf{4}}\left(\mathbf{B}_{11} \mathbf{H}_{14}\right)_{2}\left(\mathbf{B}_{12} \mathbf{H}_{12}\right)$ & $\mathbf{N a}_{\mathbf{3}}\left(\mathbf{B}_{11} \mathbf{H}_{14}\right)\left(\mathbf{B}_{12} \mathbf{H}_{12}\right)$ & $\mathbf{N a}_{\mathbf{5}}\left(\mathbf{B}_{11} \mathbf{H}_{14}\right)\left(\mathbf{B}_{12} \mathbf{H}_{12}\right)_{\mathbf{2}}$ \\
\hline Na per formula unit & 1 & 1.33 & 1.5 & 1.67 \\
\hline Space group & $P n a 2_{1}$ & $I m-3 m$ & $I m-3 m$ & $P m-3 n$ \\
\hline $\mathbf{T}\left({ }^{\circ} \mathbf{C}\right)$ & $25^{\circ} \mathrm{C}$ & $25^{\circ} \mathrm{C}$ & $25^{\circ} \mathrm{C}$ & $25^{\circ} \mathrm{C}$ \\
\hline $\begin{array}{l}\text { Crystal } \\
\text { system }\end{array}$ & Orthorhombic & Cubic & Cubic & Cubic \\
\hline $\begin{array}{l}\text { Anion } \\
\text { packing }\end{array}$ & $h c p$ & $b c c$ & $b c c$ & $b c c$ \\
\hline $\boldsymbol{a}(\mathbf{\AA})$ & $10.953(3)$ & $7.9162(2)$ & $7.9246(15.2)$ & $7.9276(2)$ \\
\hline
\end{tabular}




\begin{tabular}{|l|l|l|l|l|}
\hline $\boldsymbol{b}(\boldsymbol{\AA})$ & $12.140(2)$ & - & - & - \\
\hline $\boldsymbol{c}(\boldsymbol{\AA})$ & $7.546(2)$ & - & - & - \\
\hline $\boldsymbol{V}\left(\AA^{\mathbf{3}}\right)$ & $1003.41(0.4)$ & $496.08(3)$ & $497.66(1)$ & $498.24(3)$ \\
\hline $\boldsymbol{Z}$ & 4 & 2 & 2 & 2 \\
\hline $\boldsymbol{\rho}\left(\mathbf{g} / \mathbf{c m}^{\mathbf{3}}\right)$ & 1.03 & 1.15 & 1.14 & 1.18 \\
\hline
\end{tabular}

Figure 4 a) Differential scanning calorimetry $\left(\Delta T / \Delta t=5{ }^{\circ} \mathrm{C} / \mathrm{min}\right)$. b) Temperature dependent synchrotron radiation powder $\mathrm{X}$-ray diffraction data of $\mathrm{NaB}_{11} \mathrm{H}_{14}$ synthesized by method 2. $(\Delta T / \Delta t$ $=5{ }^{\circ} \mathrm{C} / \mathrm{min}, \lambda=0.7095 \AA$ ). Symbols: $\bullet \alpha-\mathrm{NaB}_{11} \mathrm{H}_{14}, \diamond \beta-\mathrm{NaB}_{11} \mathrm{H}_{14}$ and $\Delta \gamma-\mathrm{NaB}_{11} \mathrm{H}_{14}$.

In order to investigate the phase transitions in these compounds, we performed DSC and temperature-dependent PXRD experiments (Fig. 4). The DSC data of $\mathrm{NaB}_{11} \mathrm{H}_{14}$ reveals two endothermic events with onset temperatures of $\sim 60$ and $80^{\circ} \mathrm{C}$, which correspond to the first order polymorphic transitions of $\alpha$ - and $\beta-\mathrm{NaB}_{11} \mathrm{H}_{14}$ to $\gamma-\mathrm{NaB}_{11} \mathrm{H}_{11}$, respectively (Fig. 4a). Cooling the sample back to $20^{\circ} \mathrm{C}$ shows an exothermic event in the range of 50 to $30^{\circ} \mathrm{C}$ associated with the formation of only the $\alpha$ phase. This corresponds to the reappearance of the Bragg reflections of $\alpha$ $\mathrm{NaB}_{11} \mathrm{H}_{14}$ in the temperature-dependent PXRD data (Fig. 4b) and indicates that the $\beta$ phase is a metastable phase. The metastable character of the $\beta$ phase also explains the fading of the endothermic peak at $80^{\circ} \mathrm{C}$ apparent from the second heating cycle also shown in Fig. 4a, which corresponds to the phase transition of $\beta$ to $\gamma$ phase. As discussed above, annealing the sample at $100{ }^{\circ} \mathrm{C}$ for longer time (16 h instead of $2 \mathrm{~h}$ ) disappeared the $\beta$ phase and no endothermic peak was observed at $\sim 80{ }^{\circ} \mathrm{C}$ (Fig S15b). This is also in agreement with the previous study on $\mathrm{NaB}_{11} \mathrm{H}_{14}$, where long heat treatment was performed $\left(16 \mathrm{~h}\right.$ at $\left.100^{\circ} \mathrm{C}\right)$ and only the phase transition from $\alpha$ to $\gamma$ was observed. Additional infrared spectroscopy and differential scanning calorimetry 
measurements coupled with mass spectrometry confirmed that $\beta$-phase has the same stoichiometry $\left(\mathrm{NaB}_{11} \mathrm{H}_{14}\right)$ and is not a solvent phase (Fig. S15a,b).

The observed phase transition temperatures in $\mathrm{NaB}_{11} \mathrm{H}_{14}$ are lower than the ones observed for $\mathrm{Na}_{2} \mathrm{~B}_{10} \mathrm{H}_{10}$ and $\mathrm{NaCB}_{11} \mathrm{H}_{12}$ (transitions at $100^{\circ} \mathrm{C}$ and $107^{\circ} \mathrm{C}$, respectively) and are comparable to the phase transition temperature of $\mathrm{NaCB}_{9} \mathrm{H}_{10}$ at $\sim 50{ }^{\circ} \mathrm{C} .11,35,36$

Fig. 4a also shows DSC measurements of the mixed-anions $\mathrm{Na}_{x+2 \mathrm{y}}\left(\mathrm{B}_{11} \mathrm{H}_{14}\right)_{\mathrm{x}}\left(\mathrm{B}_{12} \mathrm{H}_{12}\right)_{\mathrm{y}}$. Interestingly, the phase transitions observed for $\mathrm{NaB}_{11} \mathrm{H}_{14}$ are fully suppressed. Suppression of the phase transition upon anion mixing was already observed for other mixed-anion compounds. ${ }^{9,12-}$ 14,33,37 Further heating of the mixed-anion compounds $\mathrm{Na}_{4}\left(\mathrm{~B}_{11} \mathrm{H}_{14}\right)_{2}\left(\mathrm{~B}_{12} \mathrm{H}_{12}\right)$ and $\mathrm{Na}_{3}\left(\mathrm{~B}_{11} \mathrm{H}_{14}\right)\left(\mathrm{B}_{12} \mathrm{H}_{12}\right)$ beyond $200{ }^{\circ} \mathrm{C}$ leads to decomposition without any phase transition (as monitored by PXRD shown in Fig. S17, S18). In contrast, heating sample $\mathrm{Na}_{5}\left(\mathrm{~B}_{11} \mathrm{H}_{14}\right)\left(\mathrm{B}_{12} \mathrm{H}_{12}\right)_{2}$ increases the disorder in the structure and a phase transition from $P m-3 n$ to $I m-3 n$ phase is observed at $254{ }^{\circ} \mathrm{C}$, as already discussed above (Fig. S16). ${ }^{14,34}$ Formation of $\alpha-\mathrm{Na}_{2} \mathrm{~B}_{12} \mathrm{H}_{12}\left(P 2_{1} / \mathrm{n}\right)^{38}$ at the decomposition temperature for the mixed-anion compounds (Fig. S16-S18) indicates that $\mathrm{Na}_{\mathrm{x}+\mathrm{y}}\left(\mathrm{B}_{11} \mathrm{H}_{14}\right)_{\mathrm{x}}\left(\mathrm{B}_{12} \mathrm{H}_{12}\right)_{\mathrm{y}}$ segregates into its parents compounds with an immediate decomposition of $\mathrm{NaB}_{11} \mathrm{H}_{14}$.

The TGA measurements of $\mathrm{NaB}_{11} \mathrm{H}_{14}$ reveal a $\sim 2 \%$ weight loss at $\sim 190{ }^{\circ} \mathrm{C}$ (Fig. S19). However, the heat treatment of $\mathrm{NaB}_{11} \mathrm{H}_{14}$ for two hours at different temperatures shows that $\mathrm{NaB}_{11} \mathrm{H}_{14}$ decomposition and formation of $\mathrm{Na}_{2} \mathrm{~B}_{12} \mathrm{H}_{12}$ and other $\mathrm{B}$ containing species already starts at $120{ }^{\circ} \mathrm{C}$ (Fig. S20b). Interestingly, the decomposition products seem to stabilize the $\gamma$ phase of $\mathrm{NaB}_{11} \mathrm{H}_{14}$ at room temperature (Fig. S20a). 
Figure 5 Arrhenius plot of the sodium ion conductivity of $\mathrm{NaB}_{11} \mathrm{H}_{14}$ and $\mathrm{Na}_{\mathrm{x}+2 \mathrm{y}}\left(\mathrm{B}_{11} \mathrm{H}_{14}\right)_{\mathrm{x}}\left(\mathrm{B}_{12} \mathrm{H}_{12}\right)_{\mathrm{y}}$ with $\mathrm{x}$ :y ratios of $2: 1,1: 1,1: 2$

The temperature dependence of the sodium ion conductivity of $\mathrm{NaB}_{11} \mathrm{H}_{14}$ and $\mathrm{Na}_{\mathrm{x}+2 \mathrm{y}}\left(\mathrm{B}_{11} \mathrm{H}_{14}\right)_{\mathrm{x}}\left(\mathrm{B}_{12} \mathrm{H}_{12}\right)_{\mathrm{y}}$ mixtures determined by electrochemical impedance spectroscopy is presented in Fig. 5. The relative densities of the pellets and particle morphologies of the samples are provided in Tab. S6 and Fig. S21 respectively. Pure $\mathrm{NaB}_{11} \mathrm{H}_{14}$ shows a conductivity of $8 \times 10^{-}$ ${ }^{5} \mathrm{~S} / \mathrm{cm}$ at room temperature which is higher than $\sim 2 \times 10^{-6} \mathrm{~S} / \mathrm{cm}$ observed for $\mathrm{NaB}_{11} \mathrm{H}_{14}$ in the previous study. ${ }^{21} \mathrm{We}$ attribute this to the higher $\gamma$ phase content in this sample. The apparent activation energy is $0.75 \mathrm{eV}$ at room temperature but reduces to $0.27 \mathrm{eV}$ at $\sim 70{ }^{\circ} \mathrm{C}$ due to the phase transition from the $\alpha, \beta$ to the $\gamma$ phase. The commercial $\mathrm{NaB}_{11} \mathrm{H}_{14}$ with an even higher amount of $\gamma$-phase (Fig S2) shows a conductivity of $3.8 \times 10^{-4} \mathrm{~S} / \mathrm{cm}$ at room temperature. In this sample, the activation energy is $0.53 \mathrm{eV}$ at room temperature and changes to $0.2 \mathrm{eV}$ at temperatures above the phase transition.

Interestingly, all three mixed-anion $\mathrm{Na}_{\mathrm{x}+2 \mathrm{y}}\left(\mathrm{B}_{11} \mathrm{H}_{14}\right)_{\mathrm{x}}\left(\mathrm{B}_{12} \mathrm{H}_{12}\right)_{\mathrm{y}}$ compounds show a significantly higher ionic conductivity than $\mathrm{NaB}_{11} \mathrm{H}_{14}$ reaching values of 3-4 mS/cm at room temperature. Although no phase transition occurs in these samples, the activation energy changes from $0.5 \mathrm{eV}$ in low temperatures to $0.3 \mathrm{eV}$ at $\sim 40{ }^{\circ} \mathrm{C}$. Similar non-Arrhenius behavior has been observed previously for $\mathrm{Na}_{4}\left(\mathrm{~B}_{10} \mathrm{H}_{10}\right)\left(\mathrm{B}_{12} \mathrm{H}_{12}\right)$ and $\mathrm{Na}_{2}\left(\mathrm{CB}_{11} \mathrm{H}_{12}\right)\left(\mathrm{CB}_{9} \mathrm{H}_{10}\right),{ }^{9,13}$ and are explained by the transition from a regime with correlated cationic motion at low temperature to a regime of noncorrelated cationic diffusion at elevated temperature. ${ }^{33}$ At low temperature, the highest conductivity is observed for $\mathrm{Na}_{4}\left(\mathrm{~B}_{11} \mathrm{H}_{14}\right)_{2}\left(\mathrm{~B}_{12} \mathrm{H}_{12}\right)$ which contains the highest $\mathrm{B}_{11} \mathrm{H}_{14}{ }^{-}$content and consequently lowest $\mathrm{Na}^{+}$content in the structure. Similar results are also observed for $\mathrm{Na}_{2}$ 
Figure 6 Linear sweep voltammetry of a) a Na/Na $\left(\mathrm{B}_{11} \mathrm{H}_{14}\right)\left(\mathrm{B}_{12} \mathrm{H}_{12}\right)_{2} / \mathrm{Al}$ cell from $1.3 \mathrm{~V}$ to $-0.1 \mathrm{~V}$ vs Na/Na ${ }^{+}$and b) a Na/Na $\left(\mathrm{B}_{11} \mathrm{H}_{14}\right)\left(\mathrm{B}_{12} \mathrm{H}_{12}\right)_{2} / \mathrm{Na}_{5}\left(\mathrm{~B}_{11} \mathrm{H}_{14}\right)\left(\mathrm{B}_{12} \mathrm{H}_{12}\right)_{2}+\mathrm{C} / \mathrm{Pt}$ cell from $2.0 \mathrm{~V}$ to $4.0 \mathrm{~V}$ vs Na/ $\mathrm{Na}^{+}$with a scan rate of $0.05 \mathrm{mV} / \mathrm{s}$ at $60{ }^{\circ} \mathrm{C}$. The linear fitted lines are shown by black dashed lines. c) Galvanostatic cycling of a symmetric $\mathrm{Na} / \mathrm{Na}_{5}\left(\mathrm{~B}_{11} \mathrm{H}_{14}\right)\left(\mathrm{B}_{12} \mathrm{H}_{12}\right)_{2} / \mathrm{Na}$ cell at $60{ }^{\circ} \mathrm{C}$ with a current densities of $25 \mu \mathrm{A} / \mathrm{cm}^{2}$ for the first $24 \mathrm{~h}$ and $50 \mu \mathrm{A} / \mathrm{cm}^{2}$ for the rest of measurement $(1 \mathrm{~h}$ at each direction).

The electrochemical stability of the mixed-anion $\mathrm{Na}_{\mathrm{x}+2 \mathrm{y}}\left(\mathrm{B}_{11} \mathrm{H}_{14}\right)_{\mathrm{x}}\left(\mathrm{B}_{12} \mathrm{H}_{12}\right)_{\mathrm{y}}$ electrolytes was assessed for $\mathrm{Na}_{5}\left(\mathrm{~B}_{11} \mathrm{H}_{14}\right)\left(\mathrm{B}_{12} \mathrm{H}_{12}\right)_{2}$ by means of linear sweep voltammetry shown in Fig. 6 (results for $\mathrm{NaB}_{11} \mathrm{H}_{14}$ are provided in Fig. S22). To determine the reductive stability limit, an Al working electrode was swept versus a $\mathrm{Na}$ metal electrode, acting as counter and the reference electrode, starting from the open-circuit voltage of $\sim 1.3 \mathrm{~V}$ to $-0.1 \mathrm{~V}$ vs $\mathrm{Na} / \mathrm{Na}^{+}$. The Al electrode was chosen as it does not alloy with sodium, so the measured current can be attributed to the reduction of 
$\mathrm{Na}_{5}\left(\mathrm{~B}_{11} \mathrm{H}_{14}\right)\left(\mathrm{B}_{12} \mathrm{H}_{12}\right)_{2}$. Fig. 6a and $\mathrm{S} 22 \mathrm{a}$ display a clear current onset at $\sim 0.15 \mathrm{~V}$, which we attribute to the electrolyte reduction. The small current at higher voltage is attributed to capacitive current contributions. The decomposition currents remain in the $\mathrm{nA}$ range until $\mathrm{Na}$ plating occurs at $\sim 0 \mathrm{~V}$. As we show below, these currents do not hinder stable stripping/plating for at least 520 hours as shown in Fig. 6c, S24.

The oxidative stability limit of $\mathrm{Na}_{5}\left(\mathrm{~B}_{11} \mathrm{H}_{14}\right)\left(\mathrm{B}_{12} \mathrm{H}_{12}\right)_{2}$ was determined following the methodology described in Ref. ${ }^{44}$, by sweeping the Pt/C working electrode against a $\mathrm{Na}$ metal counter electrode from 2.0 V to $4.0 \mathrm{~V}$. Both samples show a clear current onset at $\sim 2.6 \mathrm{~V}$ attributed to electrolyte oxidation (Fig. 6b, S22b). Current densities are higher by a factor of 100 compared to Fig. 6a and $\mathrm{S} 17 \mathrm{a}$, due to the use of high-surface-area carbon to increase the electrode/electrolyte interface and enhance the sensitivity to oxidation currents. As carbon gets sodiated at low potentials, this approach was not employed for the determination of the reductive stability. Analyzing the current density during subsequent cycles shows that the onset of oxidation currents shifts to $\geq 3.5 \mathrm{~V}$ implying the formation of a passivating or blocking layer after first oxidation (Fig. 6b dashed line and Fig. S23).

The lower stability of open-cage nido-borates compared to closed-cage closo-borates is attributed to the delocalized hydrogen atoms on the open side of the cage. Upon oxidation, these hydrogen atoms are more prone to form $\mathrm{H}_{2}$ and oxidize the cage further to divalent anions such as $\mathrm{B}_{11} \mathrm{H}_{13}{ }^{2-}$ or dimers. The formation of $\mathrm{B}_{20} \mathrm{H}_{18}{ }^{2-}$ dimer was observed after the oxidation of $\mathrm{B}_{10} \mathrm{H}_{10}{ }^{2-}{ }^{2}{ }^{5,46}$ Therefore, the possibility of extending the electrochemical stability beyond $2.6 \mathrm{~V}$ depends on the decomposition products formed at the interphase and should be investigated in more detail in the future.

Galvanostatic measurements were performed in order to investigate the long term stability of electrolyte versus $\mathrm{Na}$ metal. Sodium metal plating and stripping from $\mathrm{Na}_{5}\left(\mathrm{~B}_{11} \mathrm{H}_{14}\right)\left(\mathrm{B}_{12} \mathrm{H}_{12}\right)_{2}$ was 
studied by galvanostatic cycling of symmetric $\mathrm{Na} / \mathrm{Na}_{5}\left(\mathrm{~B}_{11} \mathrm{H}_{14}\right)\left(\mathrm{B}_{12} \mathrm{H}_{12}\right)_{2} / \mathrm{Na}$ cell. Fig. $6 \mathrm{c}$ reveals excellent cycling stability for $400 \mathrm{~h}$ at a current density of $50 \mu \mathrm{A} / \mathrm{cm}^{2}$ switching the current direction every $1 \mathrm{~h}$. Careful inspection of Fig. 6c reveals nevertheless a small increase of the overpotential from $2 \mathrm{mV}$ to $2.5 \mathrm{mV}$ after $400 \mathrm{~h}$, which we attribute to slow electrolyte reduction at the $\mathrm{Na} / \mathrm{Na}_{5}\left(\mathrm{~B}_{11} \mathrm{H}_{14}\right)\left(\mathrm{B}_{12} \mathrm{H}_{12}\right)_{2}$ interface consistent with the results in Fig. 6a. Additionally, continuing the sodium stripping and plating at room temperature showed a stable over potential up to $520 \mathrm{~h}$ (Fig. S24).

\section{Conclusion}

In summary, we investigated nido-borates as a cost-effective building block for solid electrolytes for all-solid-state batteries. Electrolytes combining nido-borate with closo-borate anions achieve a high sodium ion conductivity of 3-4 mS/cm. This value is higher than for electrolytes based purely on doubly charged closo-borate anions but comparable to electrolytes combining closo-borates with singly charged carba-closo-borates. The electrochemical stability window of open-cage nidoborates is narrower than for closed-cage closo-borates due to the delocalized hydrogen atoms on the open side of the cage and ranges from $0.15 \mathrm{~V}$ to $2.6 \mathrm{~V}$ vs Na$/ \mathrm{Na}^{+}$. A protective interlayer may be necessary to stabilize the interface between nido-borate-based electrolytes and a sodium metal anode. ${ }^{47,48}$ Nevertheless, we were able to demonstrate plating and stripping of sodium metal over an extended period of time with only a small increase in overpotential. Analogously protective coatings may enable stable cycling of cathode materials beyond $3 \mathrm{~V}$ vs Na/Na ${ }^{+},{ }^{49}$ while cathode materials such as sulfur with a theoretical capacity of $1675 \mathrm{mAh} / \mathrm{g}$ lie within the stability window. ${ }^{50}$ Carba-closo-borates, which offer a wider electrochemical stability window, ${ }^{14}$ can be synthesized from nido-borate precursors by closing the cage with a carbon atom. ${ }^{51,52}$ Other closo-borates such as $\mathrm{SnB}_{11} \mathrm{H}_{11}{ }^{2-}$ and $\mathrm{PB}_{11} \mathrm{H}_{11}{ }^{-}$were also synthesized based on the reaction of nido- $\mathrm{B}_{11} \mathrm{H}_{14}{ }^{-}$with $\mathrm{SnCl}_{2}$ and $\mathrm{PCl}_{3}{ }^{53,54}$ Therefore, we believe that the availability of a cost-effective synthesis route for nido- 
borates represents a promising strategy to develop the next-generation of hydro-borate electrolytes offering simultaneously high ionic conductivity and an extended electrochemical stability window. Methods discussed and demonstrated here for sodium are also applicable to the corresponding lithium analogues, either by direct synthesis or by cation exchange. Cycling of a lithium-sulfur battery based on a mixed-anion lithium carba-closo-borates electrolyte was recently demonstrated, demonstrating the technological potential of this class of electrolytes, when the cost is no longer an obstacle. ${ }^{12}$

\section{ASSOCIATED CONTENT}

\section{Supporting Information.}

- $\quad$ PXRD and NMR of $\mathrm{Me}_{3} \mathrm{NHB}_{11} \mathrm{H}_{14}$.

- Rietveld refinement data of the structures.

- PXRD comparison of the samples obtained by different synthesis methods and at different temperatures.

- Temperature dependent Synchrotron ration PXRD of the samples.

- Thermogravemetric analysis of $\mathrm{NaB}_{11} \mathrm{H}_{14}$ by TGA, DSC, PXRD and NMR.

- $2^{\text {nd }}$ to $5^{\text {th }}$ cycles of cyclic voltammogram of a) $\mathrm{Na} / \mathrm{NaB}_{11} \mathrm{H}_{14} / \mathrm{NaB}_{11} \mathrm{H} 14+\mathrm{C} / \mathrm{Pt}$ and b) $\mathrm{Na} / \mathrm{Na}_{5}\left(\mathrm{~B}_{11} \mathrm{H}_{14}\right)\left(\mathrm{B}_{12} \mathrm{H}_{12}\right)_{2} / \mathrm{Na}_{5}\left(\mathrm{~B}_{11} \mathrm{H}_{14}\right)\left(\mathrm{B}_{12} \mathrm{H}_{12}\right)_{2}+\mathrm{C} / \mathrm{Pt}$ cells.

- Electrochemical stability measurements of $\mathrm{NaB}_{11} \mathrm{H}_{14}$ together with Galvanostatic cycling of a symmetric $\mathrm{Na} / \mathrm{NaB}_{11} \mathrm{H}_{14} / \mathrm{Na}$ cell.

- Nyquist plots of $\mathrm{Na}_{3}\left(\mathrm{~B}_{11} \mathrm{H}_{14}\right)\left(\mathrm{B}_{12} \mathrm{H}_{12}\right)$ at different selected temperatures.

- The Bader charges on atoms in the $\mathrm{B}_{11} \mathrm{H}_{14^{-}}$anion.

- Scanning electron microscopy images of the samples.

\section{Acknowledgements}


The EMPAPOSTDOCS-II programme has received funding from the European Union's Horizon 2020 research and innovation programme under the Marie Skłodowska-Curie grant agreement number 754364. Moreover, this work was financially supported by the Swiss National Science Foundation (SNSF) through the SINERGIA project "Novel Ionic Conductors" (CRSII2_160749/1) and the NMR hardware was partially granted by the Swiss National Science Foundation (SNSF, grant no. 206021_150638/1). Additional support by InnoSuisse through funding for the Swiss Competence Center for Energy Research (SCCER) Heat and Electricity Storage under contract no. $1155-002545$ is also acknowledged. 


\section{References}

(1) Zhao, C.; Liu, L.; Qi, X.; Lu, Y.; Wu, F.; Zhao, J.; Yu, Y.; Hu, Y. S.; Chen, L. Solid-State Sodium Batteries. Adv. Energy Mater. 2018, 8 (17), 1703012. https://doi.org/10.1002/aenm.201703012.

(2) Zhou, C.; Bag, S.; Thangadurai, V. Engineering Materials for Progressive All- Solid-State Na Batteries. ACS Energy Lett. 2018, 3 (9), 2181-2198. https://doi.org/10.1021/acsenergylett.8b00948.

(3) Gao, Z.; Sun, H.; Fu, L.; Ye, F.; Zhang, Y.; Luo, W.; Huang, Y. Promises, Challenges, and Recent Progress of Inorganic Solid-State Electrolytes for All-Solid-State Lithium Batteries. Adv. Mater. 2018, 30 (17), 1705702. https://doi.org/10.1002/adma.201705702.

(4) Xue, Z.; He, D.; Xie, X. Poly(Ethylene Oxide)-Based Electrolytes for Lithium-Ion Batteries. J. Mater. Chem. A 2015, 3 (38), 19218-19253. https://doi.org/10.1039/c5ta03471j.

(5) Ngai, K. S.; Ramesh, S.; Ramesh, K.; Juan, J. C. A Review of Polymer Electrolytes: Fundamental, Approaches and Applications. Ionics (Kiel). 2016, 22 (8), 1259-1279. https://doi.org/10.1007/s11581-016-1756-4.

(6) Zheng, F.; Kotobuki, M.; Song, S.; Lai, M. O.; Lu, L. Review on Solid Electrolytes for All-Solid-State Lithium-Ion Batteries. J. Power Sources 2018, 389, 198-213. https://doi.org/10.1016/j.jpowsour.2018.04.022.

(7) Richards, W. D.; Miara, L. J.; Wang, Y.; Kim, J. C.; Ceder, G. Interface Stability in SolidState Batteries. Chem. Mater. 2016, 28 (1), 266-273. https://doi.org/10.1021/acs.chemmater.5b04082.

(8) Sakuda, A.; Hayashi, A.; Tatsumisago, M. Sulfide Solid Electrolyte with Favorable Mechanical Property for All-Solid-State Lithium Battery. Sci. Rep. 2013, 3, 2261. https://doi.org/10.1038/srep02261.

(9) Tang, W. S.; Yoshida, K.; Soloninin, A. V.; Skoryunov, R. V.; Babanova, O. A.; Skripov, A. V.; Dimitrievska, M.; Stavila, V.; Orimo, S. I.; Udovic, T. J. Stabilizing SuperionicConducting Structures via Mixed-Anion Solid Solutions of Monocarba- Closo -Borate Salts. ACS Energy Lett. 2016, 1 (4), 659-664. https://doi.org/10.1021/acsenergylett.6b00310.

(10) Tang, W. S.; Matsuo, M.; Wu, H.; Stavila, V.; Unemoto, A.; Orimo, S. I.; Udovic, T. J. Stabilizing Lithium and Sodium Fast-Ion Conduction in Solid Polyhedral-Borate Salts at Device-Relevant Temperatures. Energy Storage Mater. 2016, 4, 79-83. https://doi.org/10.1016/j.ensm.2016.03.004.

(11) Tang, W. S.; Matsuo, M.; Wu, H.; Stavila, V.; Zhou, W.; Talin, A. A.; Soloninin, A. V.; Skoryunov, R. V.; Babanova, O. A.; Skripov, A. V.; et al. Liquid-Like Ionic Conduction in Solid Lithium and Sodium Monocarba- Closo -Decaborates Near or at Room Temperature. Adv. Energy Mater. 2016, 6 (8), 1502237. https://doi.org/10.1002/aenm.201502237.

(12) Kim, S.; Oguchi, H.; Toyama, N.; Sato, T.; Takagi, S.; Otomo, T.; Arunkumar, D.; Kuwata, N.; Kawamura, J.; Orimo, S. A Complex Hydride Lithium Superionic Conductor for High-Energy-Density All-Solid-State Lithium Metal Batteries. Nat. Commun. 2019, 10 (1), 1081. https://doi.org/10.1038/s41467-019-09061-9.

(13) Duchêne, L.; Kühnel, R.-S.; Rentsch, D.; Remhof, A.; Hagemann, H.; Battaglia, C. A Highly Stable Sodium Solid-State Electrolyte Based on a Dodeca/Deca-Borate Equimolar 
Mixture. Chem. Commun. 2017, 53 (30), 4195-4198. https://doi.org/10.1039/C7CC00794A.

(14) Brighi, M.; Murgia, F.; Łodziana, Z.; Schouwink, P.; Wolczyk, A.; Černý, R. A Mixed Anion Hydroborate/Carba-Hydroborate as a Room Temperature Na-Ion Solid Electrolyte. J. Power Sources 2018, 404, 7-12.

(15) Duchêne, L.; Kühnel, R. S.; Stilp, E.; Cuervo Reyes, E.; Remhof, A.; Hagemann, H.; Battaglia, C. A Stable 3 V All-Solid-State Sodium-Ion Battery Based on a Closo-Borate Electrolyte. Energy Environ. Sci. 2017, 10 (12), 2609-2615. https://doi.org/10.1039/c7ee02420g.

(16) Lu, Z.; Ciucci, F. Metal Borohydrides as Electrolytes for Solid-State Li , Na, Mg , and Ca Batteries : A First-Principles Study. Chem. Mater. 2017, 29 (21), 9308-9319. https://doi.org/10.1021/acs.chemmater.7b03284.

(17) Murgia, F.; Brighi, M.; Černý, R. Room-Temperature-Operating Na Solid-State Battery with Complex Hydride as Electrolyte. Electrochem. commun. 2019, 106, 106534. https://doi.org/10.1016/j.elecom.2019.106534.

(18) Udovic, T. J.; Matsuo, M.; Unemoto, A.; Verdal, N.; Stavila, V.; Skripov, A. V; Rush, J. J.; Takamura, H.; Orimo, S.-I. Sodium Superionic Conduction in $\mathrm{Na}_{2} \mathrm{~B}_{12} \mathrm{H}_{12}$. Chem. Commun. (Camb). 2014, 50 (28), 3750-3752. https://doi.org/10.1039/c3cc49805k.

(19) Katchem. http://www.katchem.cz (11, 1, 2019).

(20) Gigante, A.; Duchêne, L.; Moury, R.; Pupier, M.; Remhof, A.; Hagemann, H. Direct Solution-based Synthesis of the $\mathrm{Na}_{4}\left(\mathrm{~B}_{12} \mathrm{H}_{12}\right)\left(\mathrm{B}_{10} \mathrm{H}_{10}\right)$ Solid Electrolyte. ChemSusChem 2019, 4, 4832-4837. https://doi.org/10.1002/cssc.201902152.

(21) Tang, W. S.; Dimitrievska, M.; Stavila, V.; Zhou, W.; Wu, H.; Talin, A. A.; Udovic, T. J. Order-Disorder Transitions and Superionic Conductivity in the Sodium NidoUndeca(Carba)Borates. Chem. Mater. 2017, 29 (24), 10496-10509. https://doi.org/10.1021/acs.chemmater.7b04332.

(22) Alibaba. https://www.alibaba.com (11, 1, 2019).

(23) Ringstrand, B.; Bateman, D.; Shoemaker, R. K.; Janoušek, Z. Improved Synthesis of [Closo-1- $\left.\mathrm{CB}_{9} \mathrm{H}_{10}\right]^{-}$Anion and New c-Substituted Derivatives. Collect. Czechoslov. Chem. Commun. 2009, 74 (3), 419-431. https://doi.org/10.1135/cccc2008151.

(24) Sivaev, I. B.; Prikaznov, A. V.; Naoufal, D. Fifty Years of the Closo-Decaborate Anion Chemistry. Collect. Czechoslov. Chem. Commun. 2010, 75 (11), 1149-1199. https://doi.org/10.1135/cccc2010054.

(25) Pylypko, S.; Ould-Amara, S.; Zadick, A.; Petit, E.; Chatenet, M.; Cretin, M.; Demirci, U. B. The Highly Stable Aqueous Solution of Sodium Dodecahydro-Closo-Dodecaborate $\mathrm{Na}_{2} \mathrm{~B}_{12} \mathrm{H}_{12}$ as a Potential Liquid Anodic Fuel. Appl. Catal. B Environ. 2018, 222 (c), 1-8. https://doi.org/10.1016/j.apcatb.2017.09.068.

(26) Moury, R.; Gigante, A.; Hagemann, H. An Alternative Approach to the Synthesis of $\mathrm{NaB}_{3} \mathrm{H}_{8}$ and $\mathrm{Na}_{2} \mathrm{~B}_{12} \mathrm{H}_{12}$ for Solid Electrolyte Applications. Int. J. Hydrogen Energy 2017, 42 (35), 22417-22421. https://doi.org/10.1016/j.ijhydene.2017.02.044.

(27) Aftandilian, V. D.; Miller, H. C.; Parshall, G. W.; Muetterties, E. L. Chemistry of Boranes. V. ${ }^{1}$ First Example of a $\mathrm{B}_{11}$ Hydride, the $\mathrm{B}_{11} \mathrm{H}_{14}{ }^{-}$Anion. Inorg. Chem. 1962, 1 (4), 734-737. https://doi.org/10.1021/ic50004a003.

(28) Dunks, G. B.; Barker, K.; Hedaya, E.; Hefner, C.; Palmer-Ordonez, K.; Remec, P. 
Simplified Synthesis of $\mathrm{B}_{10} \mathrm{H}_{14}$ from $\mathrm{NaBH}_{4}$ via $\mathrm{B}_{11} \mathrm{H}_{14}$ - Ion. Inorg. Chem. 1981, 20 (6), 1692-1697. https://doi.org/10.1021/ic50220a015.

(29) Dyadkin, V.; Pattison, P.; Dmitriev, V.; Chernyshov, D. A New Multipurpose Diffractometer PILATUS@SNBL. J. Synchrotron Radiat. 2016, 23, 825-829. https://doi.org/10.1107/S1600577516002411.

(30) Bergamaschi, A.; Cervellino, A.; Dinapoli, R.; Gozzo, F.; Henrich, B.; Johnson, I.; Kraft, P.; Mozzanica, A.; Schmitt, B.; Shi, X. The MYTHEN Detector for X-Ray Powder Diffraction Experiments at the Swiss Light Source. Synchrotron Radiat. 2010, 17, 653668. https://doi.org/10.1107/S0909049510026051.

(31) Volkov, O.; Radacki, K.; Thomas, R. L.; Rath, N. P.; Barton, L. A New Look at the Nido Undecaborate System. J. Organomet. Chem. 2005, 690 (11), 2736-2744. https://doi.org/10.1016/j.jorganchem.2005.02.029.

(32) McGrath, T. D.; Welch, A. J. [Ph $\left.{ }_{3} \mathrm{PH}\right]\left[\right.$ Nido-B $\left.{ }_{11} \mathrm{H}_{14}\right]$. Acta Cryst 1997, C53, 229-231. https://doi.org/10.1107/S0108270196013303.

(33) Duchêne, L.; Lunghammer, S.; Burankova, T.; Liao, W.-C.; Embs, J. P.; Copéret, C.; Wilkening, H. M. R.; Remhof, A.; Hagemann, H.; Battaglia, C. Ionic Conduction Mechanism in the $\mathrm{Na}_{2}\left(\mathrm{~B}_{12} \mathrm{H}_{12}\right)_{0.5}\left(\mathrm{~B}_{10} \mathrm{H}_{10}\right)_{0.5}$ Closo- Borate Solid-State Electrolyte: Interplay of Disorder and Ion-Ion Interactions. Chem. Mater. 2019, 31 (9), 3449-3460. https://doi.org/10.1021/acs.chemmater.9b00610.

(34) Verdal, N.; Her, J.-H.; Stavila, V.; Soloninin, A. V.; Babanova, O. a.; Skripov, A. V.; Udovic, T. J.; Rush, J. J. Complex High-Temperature Phase Transitions in $\mathrm{Li}_{2} \mathrm{~B}_{12} \mathrm{H}_{12}$ and $\mathrm{Na}_{2} \mathrm{~B}_{12} \mathrm{H}_{12}$. J. Solid State Chem. 2014, 212, 81-91.

https://doi.org/10.1016/j.jssc.2014.01.006.

(35) Udovic, T. J.; Matsuo, M.; Tang, W. S.; Wu, H.; Stavila, V.; Soloninin, A. V; Skoryunov, R. V; Babanova, O. a; Skripov, A. V; Rush, J. J.; et al. Exceptional Superionic Conductivity in Disordered Sodium Decahydro-Closo-Decaborate. Adv. Mater. 2014, 26 (45), 7622-7626. https://doi.org/10.1002/adma.201403157.

(36) Tang, W. S.; Unemoto, A.; Zhou, W.; Stavila, V.; Matsuo, M.; Wu, H.; Orimo, S.; Udovic, T. J. Unparalleled Lithium and Sodium Superionic Conduction in Solid Electrolytes with Large Monovalent Cage-like Anions. Energy Environ. Sci. 2015, 8 (12), 3637-3645. https://doi.org/10.1039/C5EE02941D.

(37) Sadikin, Y.; Brighi, M.; Schouwink, P.; Černý, R. Superionic Conduction of Sodium and Lithium in Anion-Mixed Hydroborates $\mathrm{Na}_{3} \mathrm{BH}_{4} \mathrm{~B}_{12} \mathrm{H}_{12}$ and $\left(\mathrm{Li}_{0.7} \mathrm{Na}_{0.3}\right)_{3} \mathrm{BH}_{4} \mathrm{~B}_{12} \mathrm{H}_{12}$. Adv. Energy Mater. 2015, 5 (21), 1501016. https://doi.org/10.1002/aenm.201501016.

(38) Her, J. H.; Zhou, W.; Stavila, V.; Brown, C. M.; Udovic, T. J. Role of Cation Size on the Structural Behavior of the Alkali-Metal Dodecahydro-Closo-Dodecaborates. J. Phys. Chem. C 2009, 113 (26), 11187-11189. https://doi.org/10.1021/jp904980m.

(39) Wenzel, S.; Leichtweiss, T.; Weber, D. A.; Sann, J.; Zeier, W. G.; Janek, J. Interfacial Reactivity Benchmarking of the Sodium Ion Conductors $\mathrm{Na}_{3} \mathrm{PS}_{4}$ and Sodium $\beta$-Alumina for Protected Sodium Metal Anodes and Sodium All-Solid-State Batteries. ACS Appl. Mater. Interfaces 2016, 8 (41), 28216-28224. https://doi.org/10.1021/acsami.6b10119.

(40) Bay, M. C.; Heinz, M. V. F.; Figi, R.; Schreiner, C.; Basso, D.; Zanon, N.; Vogt, U. F.; Battaglia, C. Impact of Liquid Phase Formation on Microstructure and Conductivity of LiStabilized Na-B"-Alumina Ceramics. ACS Appl. Energy Mater. 2019, 2 (1), 687-693. https://doi.org/10.1021/acsaem.8b01715. 
(41) Zhang, Z.; Zhang, Q.; Shi, J.; Chu, Y. S.; Yu, X.; Xu, K.; Ge, M.; Yan, H.; Li, W.; Gu, L.; et al. A Self-Forming Composite Electrolyte for Solid-State Sodium Battery with Ultralong Cycle Life. Adv. Energy Mater. 2017, 7 (4), 1601196. https://doi.org/10.1002/aenm.201601196.

(42) Zhang, Z.; Ramos, E.; Lalère, F.; Assoud, A.; Kaup, K.; Hartman, P.; Nazar, L. F. $\mathrm{Na}_{11} \mathrm{Sn}_{2} \mathrm{PS}_{12}$ : A New Solid State Sodium Superionic Conductor. Energy Environ. Sci. 2018, 11 (1), 87-93. https://doi.org/10.1039/C7EE03083E.

(43) Zhang, L.; Yang, K.; Mi, J.; Lu, L.; Zhao, L.; Wang, L.; Li, Y.; Zeng, H. Na ${ }_{3} \mathrm{PSe}_{4}$ : A Novel Chalcogenide Solid Electrolyte with High Ionic Conductivity. Adv. Energy Mater. 2015, 5 (24), 1501294. https://doi.org/10.1002/aenm.201501294.

(44) Asakura, R.; Duchêne, L.; Kühnel, R.-S.; Remhof, A.; Hagemann, H.; Battaglia, C. Electrochemical Oxidative Stability of Hydroborate-Based Solid-State Electrolytes. ACS Appl. Energy Mater. 2019, 2 (9), 6924-6930. https://doi.org/10.1021/acsaem.9b01487.

(45) Morris, J. H.; Gysling, H. J.; Reed, D. Electrochemistry of Boron Compounds. Chem. Rev. 1985, 85 (1), 51-76. https://doi.org/10.1021/cr00065a003.

(46) Duchêne, L.; Remhof, A.; Hagemann, H.; Battaglia, C. Status and Prospects of Hydroborate Electrolytes for All-Solid-State Batteries. Energy Storage Mater. 2019. https://doi.org/10.1016/j.ensm.2019.08.032.

(47) Lu, Y.; Cai, Y.; Zhang, Q.; Liu, L.; Niu, Z.; Chen, J. A Compatible Anode/SuccinonitrileBased Electrolyte Interface in All-Solid-State $\mathrm{Na}-\mathrm{CO}_{2}$ Batteries. Chem. Sci. 2019, 10 (15), 4306-4312. https://doi.org/10.1039/C8SC05178J.

(48) Luo, W.; Lin, C.; Zhao, O.; Noked, M.; Zhang, Y.; Rubloff, G. W.; Hu, L. Ultrathin Surface Coating Enables the Stable Sodium Metal Anode. Adv. Energy Mater. 2017, 7 (2), 1601526. https://doi.org/10.1002/aenm.201601526.

(49) Lau, J.; DeBlock, R. H.; Butts, D. M.; Ashby, D. S.; Choi, C. S.; Dunn, B. S. Sulfide Solid Electrolytes for Lithium Battery Applications. Adv. Energy Mater. 2018, 8 (27), 1800933. https://doi.org/10.1002/aenm.201800933.

(50) Rosenman, A.; Markevich, E.; Salitra, G.; Aurbach, D.; Garsuch, A.; Chesneau, F. F. Review on Li-Sulfur Battery Systems: An Integral Perspective. Adv. Energy Mater. 2015, 5 (16), 1500212. https://doi.org/10.1002/aenm.201500212.

(51) Toom, L.; Kütt, A.; Leito, I. Simple and Scalable Synthesis of the Carborane Anion $\mathrm{CB}_{11} \mathrm{H}_{12}$. Dalt. Trans. 2019, 48 (22), 7499-7502. https://doi.org/10.1039/c9dt01062a.

(52) Franken, A.; King, B. T.; Rudolph, J.; Rao, P.; Noll, B. C.; Michl, J. Preparation of [Closo$\left.\mathrm{CB}_{11} \mathrm{H}_{12}\right]^{-}$by Dichlorocarbene Inser-Tion into [Nido- $\left.\mathrm{B}_{11} \mathrm{H}_{14}\right]^{-}$. Collect. Czechoslov. Chem. Commun. 2001, 66 (8), 1238-1249.

(53) Chapman, R. W.; Kester, J. G.; Folting, K.; Streib, W. E.; Todd, L. J. Synthesis and Chemistry of $\mathrm{B}_{11} \mathrm{H}_{11} \mathrm{Sn}^{2-}$ and Its Germanium and Lead Analogues. Crystal Structure of $\left[\mathrm{B}_{11} \mathrm{H}_{11} \mathrm{SnCH}_{3}\right] \mathrm{PPh}_{3} \mathrm{CH}_{3} \cdot \mathrm{CH}_{2} \mathrm{Cl}_{2}$. Inorg. Chem. 1992, 31 (6), 979-983. https://doi.org/10.1021/ic00032a011.

(54) Little, J. L.; Whitesell, M. A.; Chapman, R. W.; Kester, J. G.; Huffman, J. C.; Todd, L. J. Syntheses of Some 10-, 11-, and 12-Atom Phosphaboranes. Crystal Structure of 2(Trimethylamine)-1- $\mathrm{PB}_{11} \mathrm{H}_{10}$. Inorg. Chem. 1993, 32 (15), 3369-3372. https://doi.org/10.1021/ic00067a030. 


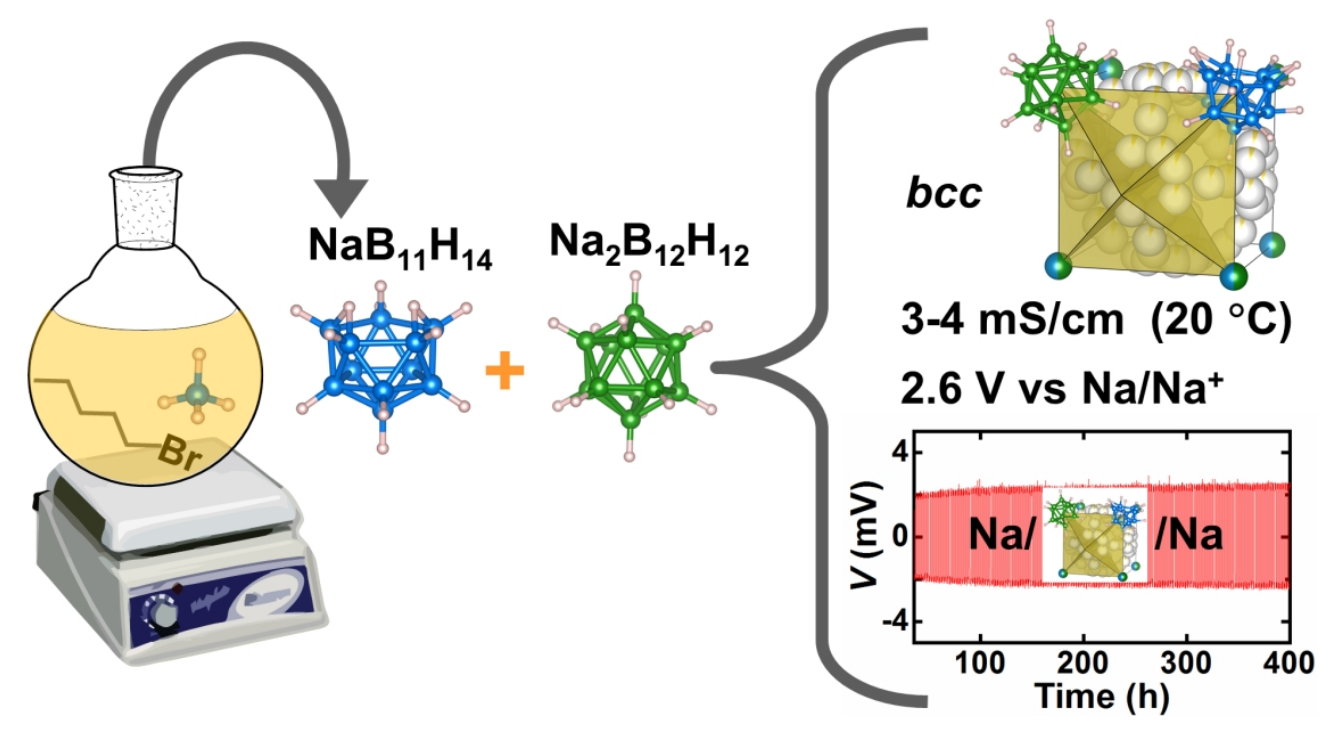

$82 \times 44 \mathrm{~mm}(600 \times 600$ DPI $)$ 
a)

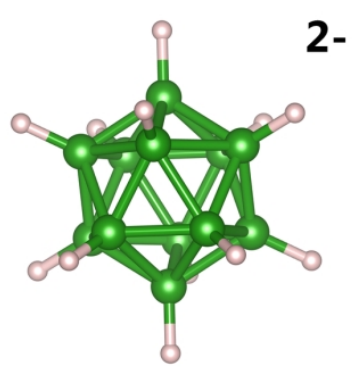

c)

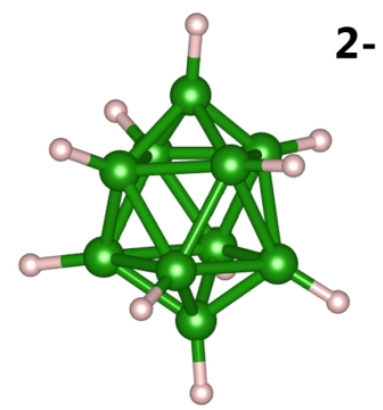

2-

e)

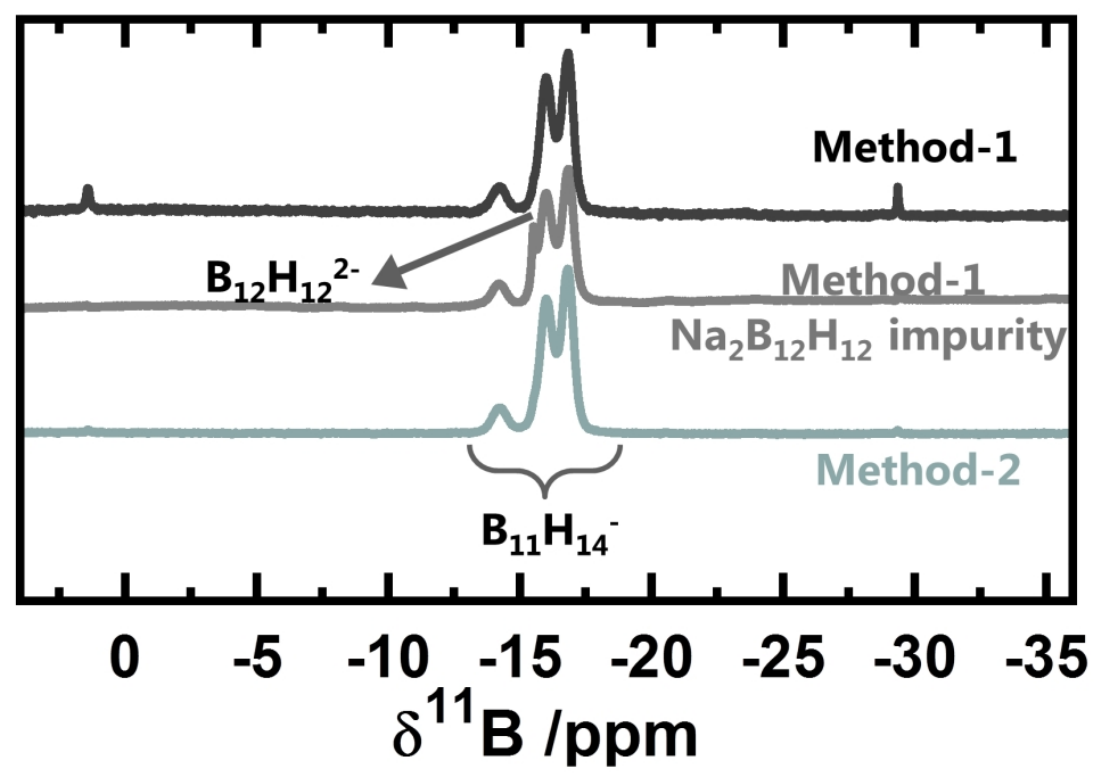

Figure 1 Atomic structure of the a) $\mathrm{B}_{12} \mathrm{H}_{12}{ }^{2-}$, b) $\mathrm{CB}_{11} \mathrm{H}_{12}{ }^{-}$, c) $\mathrm{B}_{10} \mathrm{H}_{10^{2-}}$ and d) $\mathrm{B}_{11} \mathrm{H}_{14^{-}}$polyanions. Boron is denoted by green and blue, carbon by brown and hydrogen by white balls. e) ${ }^{11} \mathrm{~B}\left\{{ }^{1} \mathrm{H}\right\}$ NMR spectra of the synthesized samples in DMSO- $d_{6}$ solutions.

$79 \times 99 \mathrm{~mm}(600 \times 600 \mathrm{DPI})$ 

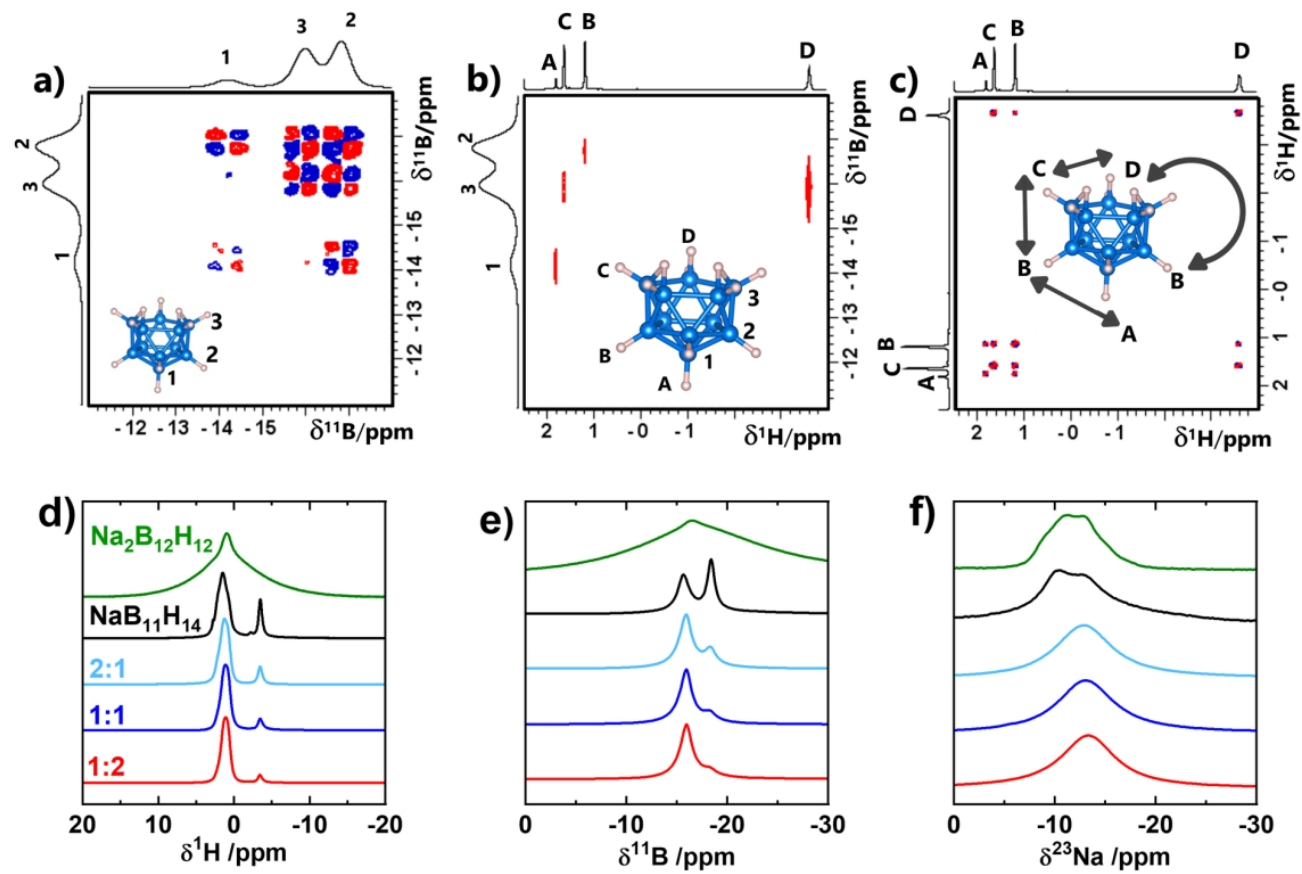

e)
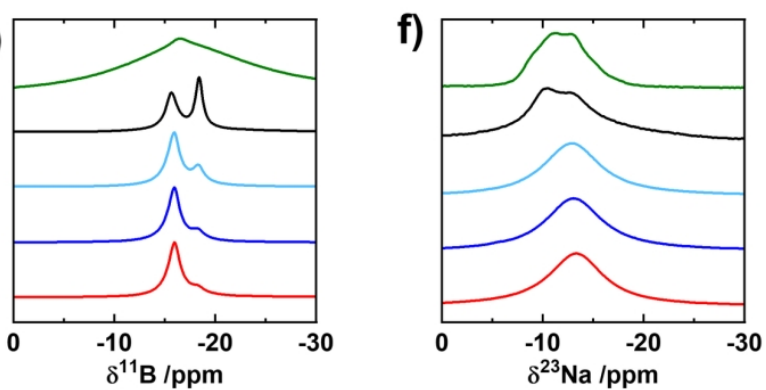

Figure 2 a) ${ }^{11} \mathrm{~B}-{ }^{11} \mathrm{~B}\left\{{ }^{1} \mathrm{H}\right\}$ DQF-COSY, b) ${ }^{1} \mathrm{H}^{11} \mathrm{~B}$ HSQC c) ${ }^{1} \mathrm{H}-{ }^{1} \mathrm{H}\left\{{ }^{11} \mathrm{~B}\right\}$ DQF-COSY solution-state 2D NMR spectra of $\mathrm{NaB}_{11} \mathrm{H}_{14}$ with assignments of resonances and d-f) solid-state ${ }^{1} \mathrm{H},{ }^{1{ }^{11}} \mathrm{~B}$ and ${ }^{23} \mathrm{Na}$ MAS NMR spectra of $\mathrm{Na}_{2} \mathrm{~B}_{12} \mathrm{H}_{12}, \mathrm{NaB}_{11} \mathrm{H}_{14}$ and $\mathrm{Na}_{x+2 \mathrm{y}}\left(\mathrm{B}_{11} \mathrm{H}_{14}\right)_{x}\left(\mathrm{~B}_{12} \mathrm{H}_{12}\right)_{y}$ compounds with $\mathrm{x}: \mathrm{y}$ ratios of $2: 1,1: 1,1: 2$.

$160 \times 119 \mathrm{~mm}(300 \times 300 \mathrm{DPI})$ 
a)

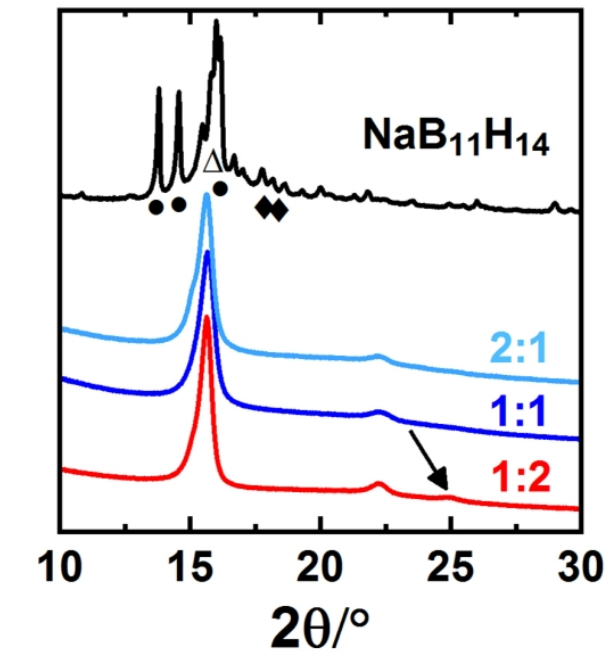

c) $2: 1,1: 1, \mathrm{Im}-3 \mathrm{~m}$

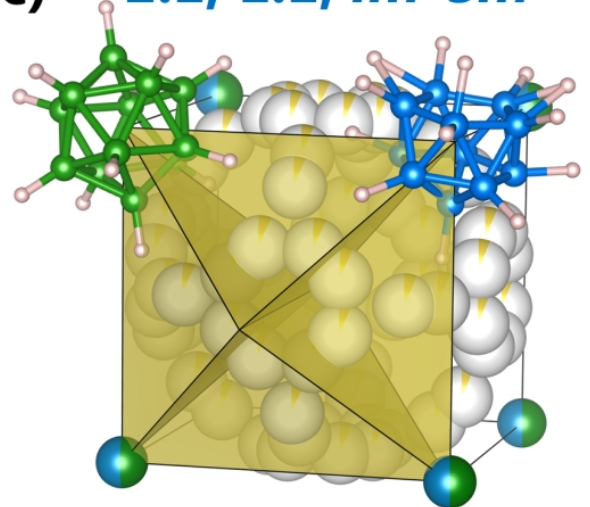

b) $\mathrm{NaB}_{11} \mathrm{H}_{14}, \mathrm{Pna2}_{1}$

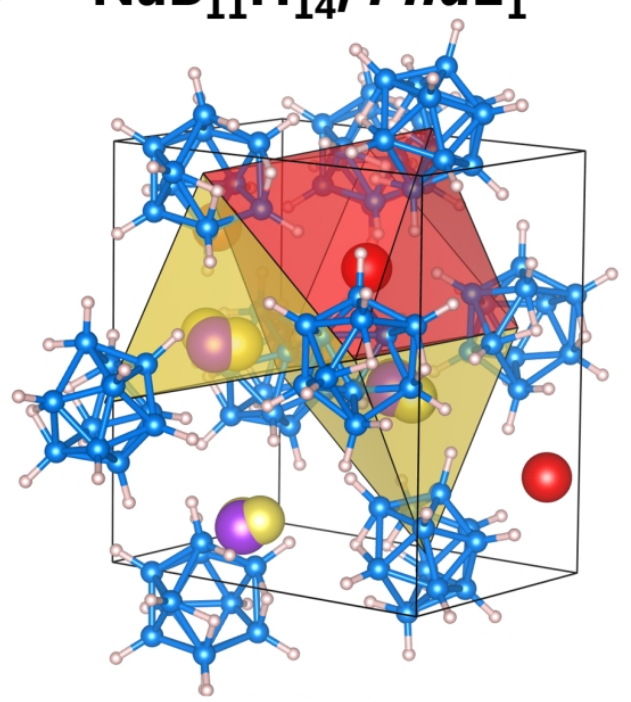

d)

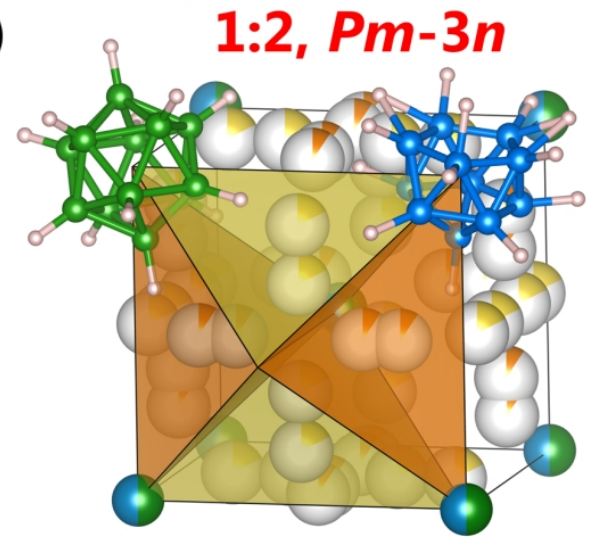

a) PXRD of $\mathrm{NaB}_{11} \mathrm{H}_{14}$ and $\mathrm{Na}_{x+2 y}\left(\mathrm{~B}_{11} \mathrm{H}_{14}\right)_{x}\left(\mathrm{~B}_{12} \mathrm{H}_{12}\right)_{y}$. b-d) Crystal structures of $\mathrm{NaB}_{11} \mathrm{H}_{14}$ and $\mathrm{Na}_{x+2 y}\left(\mathrm{~B}_{11} \mathrm{H}_{14}\right)_{x}\left(\mathrm{~B}_{12} \mathrm{H}_{12}\right)_{y}$ compounds. In $\mathrm{NaB}_{11} \mathrm{H}_{14}$ at room temperature, sodium atoms are located in octahedral and tetrahedral positions represented by red and yellow balls. The location of sodium atoms in the ordered phase at $-110^{\circ} \mathrm{C}$ is represented by purple balls.

$79 \times 79 m m(600 \times 600$ DPI $)$ 

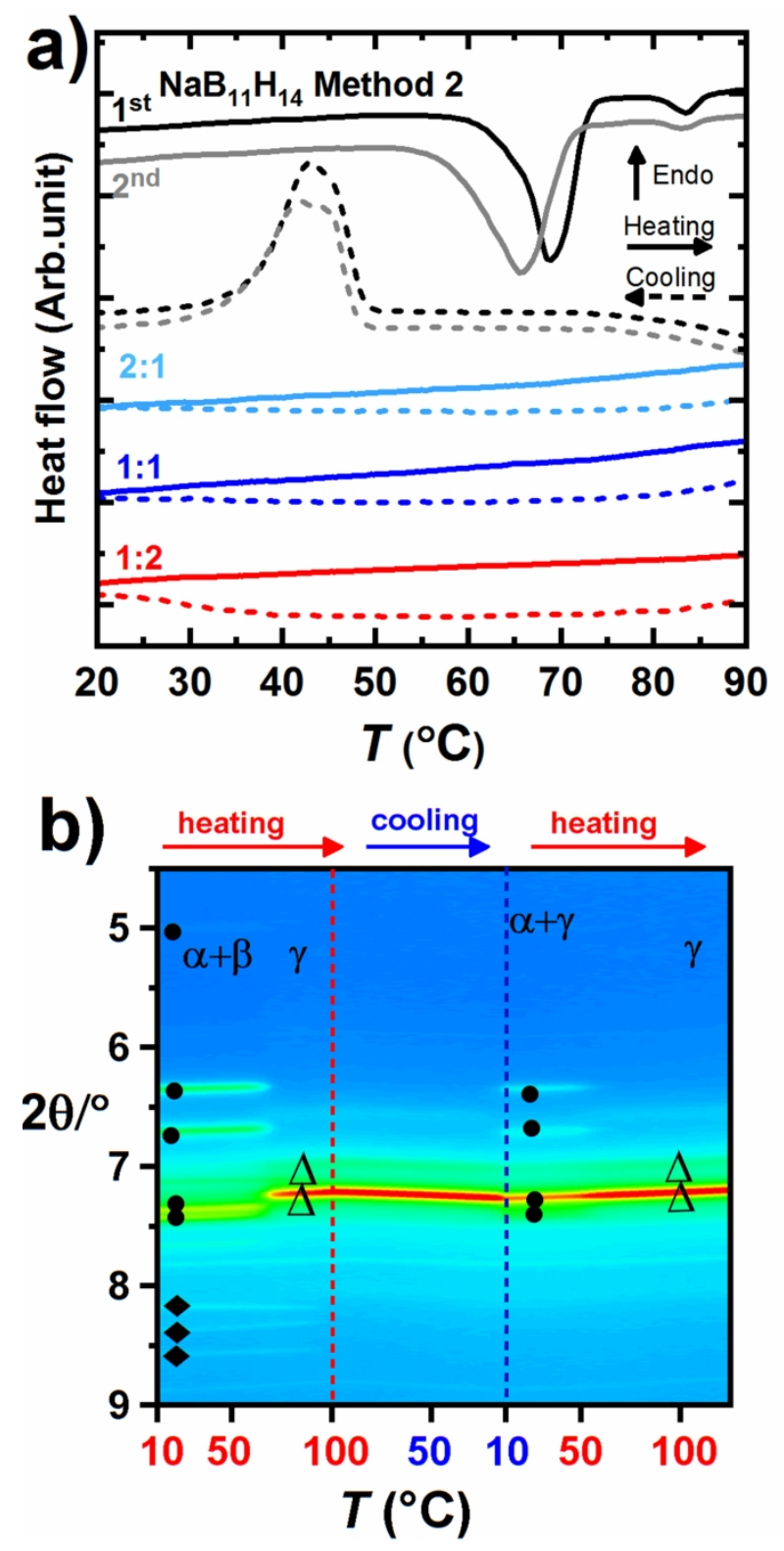

Figure 4 a) Differential scanning calorimetry $\left(\Delta T / \Delta t=5^{\circ} \mathrm{C} / \mathrm{min}\right)$. b) Temperature dependent synchrotron radiation powder $\mathrm{X}$-ray diffraction data of $\mathrm{NaB}_{11} \mathrm{H}_{14}$ synthesized by method 2 . $\left(\Delta T / \Delta t=5^{\circ} \mathrm{C} / \mathrm{min}, \lambda=\right.$ $0.7095 \AA)$.

$79 \times 159 \mathrm{~mm}(488 \times 488$ DPI $)$ 


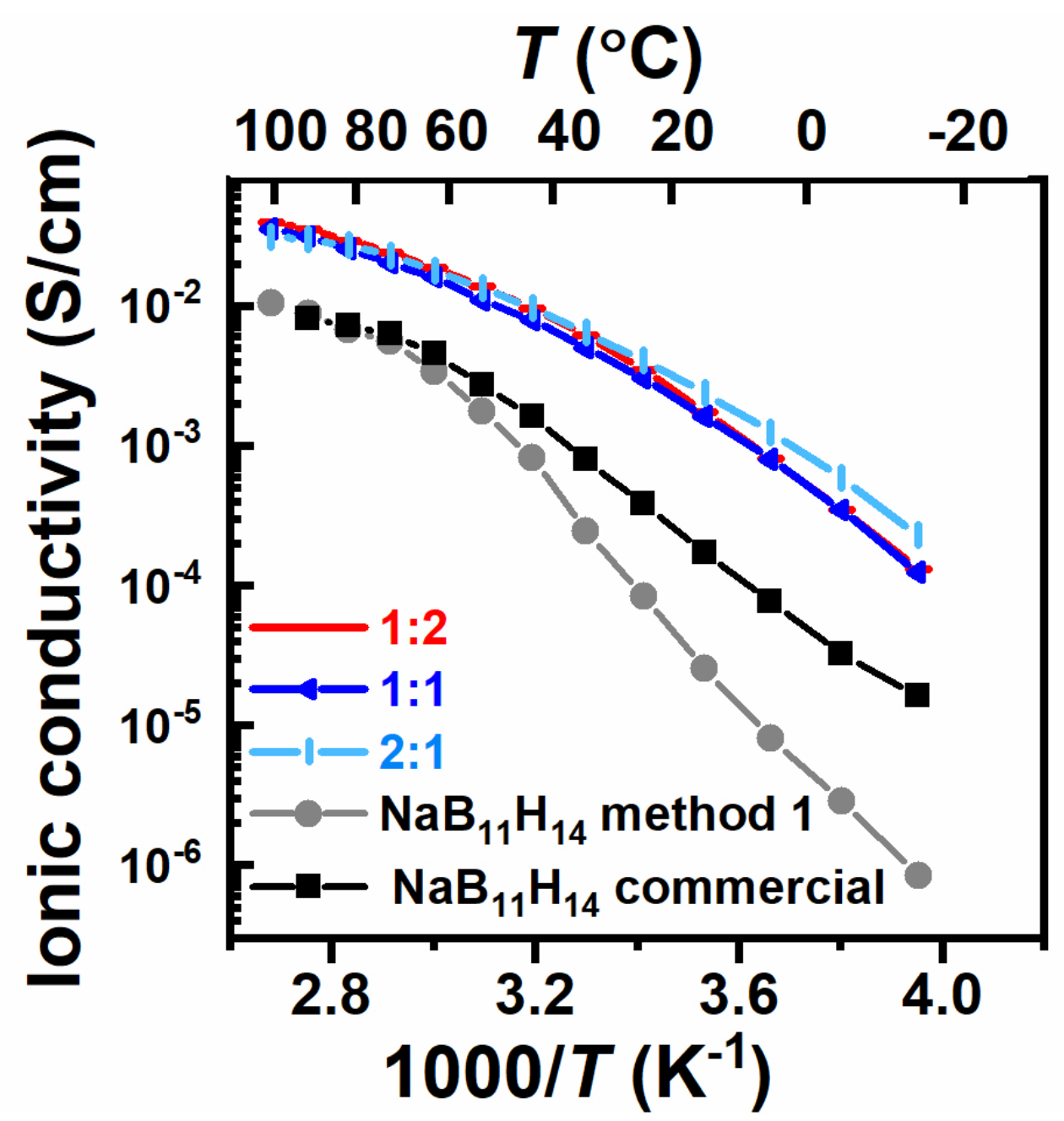

Figure 5 Arrhenius plot of the sodium ion conductivity of $\mathrm{NaB}_{11} \mathrm{H}_{14}$ and $\mathrm{Na}_{\mathrm{x}+2 \mathrm{y}}\left(\mathrm{B}_{11} \mathrm{H}_{14}\right)_{\mathrm{x}}\left(\mathrm{B}_{12} \mathrm{H}_{12}\right)_{\mathrm{y}}$ with $\mathrm{x}$ :y ratios of $2: 1,1: 1,1: 2$

$80 \times 80 \mathrm{~mm}(300 \times 300 \mathrm{DPI})$ 

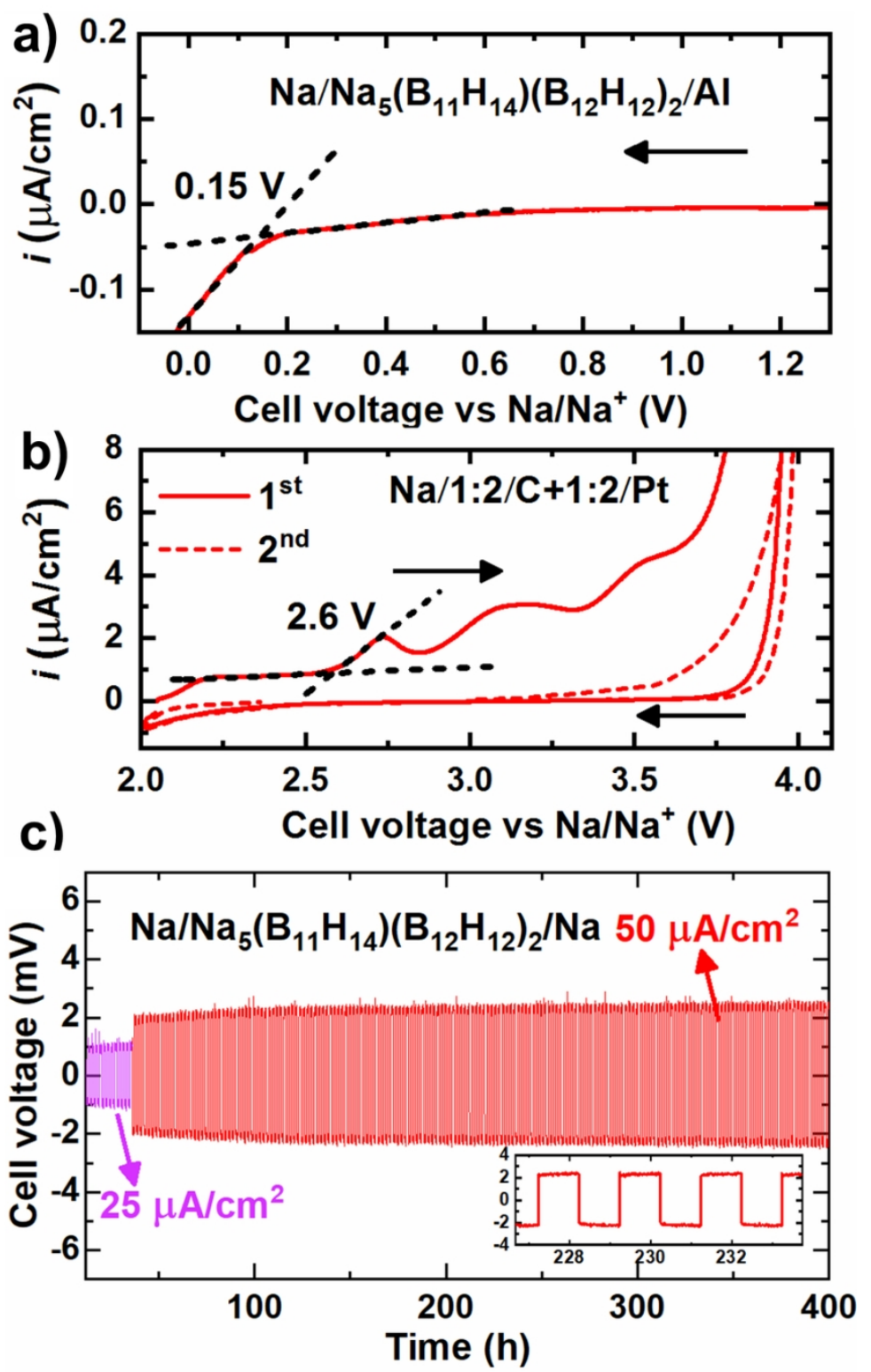

Figure 6 Linear sweep voltammetry of a) a Na/Na $\left(\mathrm{B}_{11} \mathrm{H}_{14}\right)\left(\mathrm{B}_{12} \mathrm{H}_{12}\right)_{2} / \mathrm{Al}$ cell from $1.3 \mathrm{~V}$ to $-0.1 \mathrm{~V} \mathrm{vs} \mathrm{Na/Na}{ }^{+}$ and b) a Na/Na ${ }_{5}\left(\mathrm{~B}_{11} \mathrm{H}_{14}\right)\left(\mathrm{B}_{12} \mathrm{H}_{12}\right){ }_{2} / \mathrm{Na}_{5}\left(\mathrm{~B}_{11} \mathrm{H}_{14}\right)\left(\mathrm{B}_{12} \mathrm{H}_{12}\right)_{2}+\mathrm{C} / \mathrm{Pt}$ cell from $2.0 \mathrm{~V}$ to $4.0 \mathrm{~V} \mathrm{vs} \mathrm{Na} / \mathrm{Na}^{+}$with a scan rate of $0.05 \mathrm{mV} / \mathrm{s}$ at $60^{\circ} \mathrm{C}$. The linear fitted lines are shown by black dashed lines. C) Galvanostatic cycling of a symmetric $\mathrm{Na} / \mathrm{Na}_{5}\left(\mathrm{~B}_{11} \mathrm{H}_{14}\right)\left(\mathrm{B}_{12} \mathrm{H}_{12}\right)_{2} / \mathrm{Na}$ cell at $60^{\circ} \mathrm{C}$ with current densities of $25 \mu \mathrm{A} / \mathrm{cm}^{2}$ for the first $24 \mathrm{~h}$ and $50 \mu \mathrm{A} / \mathrm{cm}^{2}$ for the rest of measurement (1 $\mathrm{h}$ at each direction).

$79 \times 129 \mathrm{~mm}(300 \times 300 \mathrm{DPI})$ 